\title{
Fundamentals of the Use of Ozone Therapy in the Treatment of Aesthetic Disorders: A Review
}

\author{
Fábio dos Santos Borges ${ }^{1 *}$, Patricia Froes Meyer ${ }^{2}$, Rodrigo Soliva Jahara ${ }^{3}$, \\ Eneida de Morais Carreiro' ${ }^{2}$, Pietro Antônio Antonuzzo4, Felice Picariello5, Cesare Di Palma6
}

${ }^{1}$ Estácio de Sá University, Rio de Janeiro, Brazil

${ }^{2}$ University Center of Rio Grande do Norte (UNIRN), Natal, Brazil

${ }^{3}$ Gama Filho University (UGF), Rio de Janeiro, Brazil

${ }^{4}$ Smart Clinic, Policlinico San Donato E Wellness Clinic Palazzo Della Salute-Gruppo San Donato, Milan, Italy

${ }^{5}$ Università degli Studi di Napoli Federico II, Napoli, Italy

${ }^{6}$ Ospedale A. Cardarelli di Napoli, Napoli, Italy

Email: ^fabioborges2000@gmail.com

How to cite this paper: Borges, F.S., Meyer, P.F., Jahara, R.S., de Morais Carreiro, E., Antonuzzo, P.A., Picariello, F. and Di Palma, C. (2021) Fundamentals of the Use of Ozone Therapy in the Treatment of Aesthetic Disorders: A Review. Journal of Biosciences and Medicines, 9, 40-70.

https://doi.org/10.4236/jbm.2021.912005

Received: October 21, 2021

Accepted: November 30, 2021

Published: December 3, 2021

Copyright $\odot 2021$ by author(s) and Scientific Research Publishing Inc. This work is licensed under the Creative Commons Attribution International License (CC BY 4.0).

http://creativecommons.org/licenses/by/4.0/

\begin{abstract}
Considering the great interest of many professionals in the foundation that guides the effective use of ozone therapy in the treatment of aesthetic disorders, this study aims to define the physiological and practical aspects of using the oxygen-ozone mixture to solve aesthetic problems. Exploratory research was carried out, presented in a narrative review, to highlight the action of ozone therapy in the treatment of aesthetic affections. The review explored scientific articles, books, theses, and dissertations published and available in the following databases: MEDLINE (Medical Literature Analysis and Retrieval System Online), PubMed (National Library of Medicine), SCIELO (Scientific Electronic Library Online), and LILACS (Latin Literature American and the Caribbean in Health Sciences). In addition, elements that characterize the authors' clinical experience on ozone therapy in various aesthetic treatment protocols were added. We found several reports in the literature that justify the use of ozone and its different therapeutic modalities in various aesthetic affections, mainly in the treatment of localized fat, cellulite, rejuvenation, skin tissue repair, acne, dyschromia, and others. Through its various therapeutic modalities, we conclude that ozone therapy has added a lot to aesthetic procedures, mainly for its effective supporting action or as the main agent of critical physiological changes to enhance clinical results when treating aesthetic conditions.
\end{abstract}

\section{Keywords}

Ozone, Ozone Therapy, Celulite, Rejuvenation, Acne 


\section{Introduction}

According to Rubin [1], on March 13, 1839, Christian Schönbein drew attention to the fact that the electrolysis of water causes a characteristic odour developed in the region of the positive electrode of the polarized current. This odor had, of course existed since the occurrence of lightning in the presence of an oxygen atmosphere on Earth, and this was known as the "odour of electricity" Schönbein proposed the name ozone for the new substance since the word ozone comes from the Greek script for odour, ozein [1].

In 1848, Hunt researched the oxidizing properties of ozone and defined that its molecular structure was formed by a triatomic triangle of oxygen, an allotropic form of $\mathrm{O}_{2}$. In 1950, two German doctors, Joachim Hänsler and Hans Wolff, manufactured the first medical ozone generator, with which it was possible to dose and graduate the concentrations of the oxygen-ozone mixture [2] [3].

Ozone therapy has been used and extensively studied for many decades; its therapeutic action is proven, consistent and with minimal side effects, as ozone is considered a biomolecule, as it is naturally produced by activated neutrophils when they participate in the body's defence [4] [5] [6].

Its effectiveness in promoting health in general is notorious throughout the world. However, besides promoting health, the use of ozone therapy in the treatment of aesthetic dysfunctions is already a reality, with good clinical results, since the beginning of the 2000s, mainly in Russia [7] [8] [9] [10].

Currently, we find support in the literature for the use of the oxygen-ozone mixture for the treatment of various aesthetic dysfunctions, such as localized fat, cellulite, wrinkles and flaccidity, acne, hyperchromia, stretch marks, telangiectasias etc. [11] [12] [13] [14] [15].

The main routes of administration used for the treatment of aesthetic affections are transcutaneous, such as bags, compresses, cups, ozonized oil, ozonized water, and invasive ones, such as rectal insufflation, and gas injection, intradermal and subcutaneously [16] [17] [18] [19] [20].

Given the great interest of many professionals in the foundation that guides the effective use of ozone therapy in the treatment of aesthetic disorders, this study aims to describe, through a literature review, the physiological and practical aspects of using the oxygen-ozone mixture to treat aesthetic problems.

\section{Materials and Methods}

This study is characterized by exploratory research, presented through a narrative review, to highlight the action of ozone therapy in the treatment of aesthetic affections. The review explored scientific articles, books, theses, and dissertations published and available in the following databases: MEDLINE (Medical Literature Analysis and Retrieval System Online), PubMed (National Library of Medicine), SCIELO (Scientific Electronic Library Online), and LILACS (Literature of Latin America and the Caribbean on Health Sciences).

As inclusion criteria, sources were selected that mentioned the aesthetic con- 
dition or described the physiology of ozone therapy related to the treated condition. Sources that did not present the abstract, were not allocated to scientific journals, and did not address the study topic, as well as those that did not support reliable data collection and those that did not support reliable data collection were discarded.

The bibliographic survey was carried out using Portuguese, English, Spanish, and Russian/Ukrainian languages, with the following descriptors: ozone, ozone therapy, aesthetic affections, cellulite, localized fat, stretch marks, wrinkles, and acne.

\section{Result and Discussion}

The search in the databases revealed 31 studies related to ozone therapy as an effective resource for the treatment of aesthetic disorders, published in the period between 2004 and 2021. Next, we will describe the physiological aspects that guide the action of ozone directly or indirectly for the treatment of various aesthetic conditions and the treatment protocols described in the literature and commonly found in the Brazilian aesthetics market.

\section{Ozone Physiology Applied to Aesthetic Dysfunctions}

We start by describing some important physiological aspects that are directly linked to the action of ozone in various aesthetic conditions to understand its mechanism of action and how we can use it in the treatment.

\subsection{Circulatory Stimulus and Increased Tissue Oxygenation}

Several aesthetic affections need a circulatory increment for their recovery, such as cellulitis, surgical dehiscence, suture stitch ruptures, necrotic areas, etc. Therefore, the use of systemically or locally applied ozone can be a powerful ally in the treatment of these clinical situations.

The use of therapeutic ozone can increase the production of nitric oxide (NO), thus increasing the local microcirculation, and this can generate beneficial effects in chronic degenerative diseases, especially chronic vascular diseases. Moreover, although NO has a half-life of less than 1 second when bound to proteins, it can exert vasodilation at distant ischemic vascular sites, producing relevant therapeutic effects [4]. In auto-haemotherapy, for example, endothelial cells can be activated by albumin-LOP and by plasma S-nitrosothiols and S-nitrosohemoglobin (precursors of NO), thus increasing the production of nitric oxide. Furthermore, in addition to improving blood circulation, there is also greater delivery of oxygen to tissues through increased levels of 2,3-Diphosphoglycerate (DPG) (combined effect of NO and Carbon Monoxide), thus decreasing the affinity of haemoglobin for oxygen, which leads to an increase in the amount of oxygen released to the tissues. Thus, the amount of oxygen that goes to the cell is increased, which can reduce the hypoxic zones, an effect especially indicated for cases of cellulitis, postoperative tissue necrosis, etc. [4] [20] [21] [22]. 


\subsection{Anti-Inflammatory}

Inflammatory processes can be present in several affections in the aesthetic area, and the use of ozone on inflamed tissues is one of the most outstanding actions of this therapeutic resource in aesthetics.

The use of ozone can reduce the production of pro-inflammatory cytokines such as Interleukin-2 (IL-2), Interleukin-4 (IL-4), Interferon-Gamma (IFN- $\gamma$ ), Tumour Necrosis Factor-Alpha (TNF)- $\alpha$ ), Interleukin 17a (IL-17a), Transforming Growth Factor- $\beta$ (TGF- $\beta$ ), Interleukin- $1 \beta$ (IL- $1 \beta$ ), and Interleukin-6 (IL-6) which are increased in inflammatory processes, including chronic ones, and by decreasing these pro-inflammatory mediators, it can also reduce inflammatory pain [23] [24] [25].

According to some authors, other biochemical actions of ozone in fighting inflammation are: increase in high-density lipoprotein (it has an anti-inflammatory action); and reduce some inflammatory compounds, such as C-reactive protein, total cholesterol, low-density lipoprotein, triglycerides, and homocysteine [14].

Ozone can also oxidize compounds with double carbon bonds, such as arachidonic acid and its derivatives (prostaglandins and leukotrienes), which are biologically active substances that participate in the maintenance of inflammatory processes [26].

There is also another essential transcription factor associated with the inflammatory process, the Nuclear Factor Kappa-B (NF- $\kappa \mathrm{B})$, which is a protein complex that activates several cellular responses and is stimulated by some cytokines (IL- 1 and TNF- $\alpha$ ) and by Reactive Oxygen Species (ROS), associated with oxidative stress [27].

However, one of the most emphasized actions in the literature on the antiinflammatory action of ozone is based on its effect on the Erythroid Nuclear Factor 2 Related to Factor 2 (Nrf2), which is a powerful protein located inside each cell of the body (Linked to Keap-1) protein. When activated, induces the synthesis of antioxidant enzymes, such as Superoxide Dismutase (SOD), Catalase (CAT), and Heme Oxygenase 1 (HO1), among others [28]. The primary function of Nrf2 is to respond to oxidative stress by activating antioxidant genes [29]. It is the key regulator of the body's antioxidant response [30].

The use of ozone is capable of stimulating Nrf2, generating a great antioxidant effect. With this, it is possible to obtain the inhibition of NF- $\kappa \mathrm{B}$, consequently, a decrease in the inflammatory process. Nrf2 can modulate inflammation through the suppression of pro-inflammatory genes directly or through the inhibition of NF- $\kappa$ B [31] [32] [33].

The systemic treatment with ozone increased Nrf2 levels in peripheral blood mononuclear cells, with consequent improved activity of superoxide dismutase and catalase. Systemic ozone in rats activated Nrf2 and inhibited the NF $\kappa \mathrm{B}$ pathway; thus, it was able to activate antioxidant enzymes and decreased inflammatory cytokines in animal kidneys, decreasing renal failure and tubulointerstitial damage [34]. 
Rectal insufflation with ozone in patients with Multiple Sclerosis increased Nrf2 expression in mononuclear cells, improving antioxidant enzymes' activity, and reducing pro-inflammatory cytokines' levels [35].

The protective effect of ozone therapy in severe SARS-CoV-2 infection was achieved through its anti-inflammatory property through the increased antioxidant activity of Nrf2 [31].

In the aesthetic clinic, we are faced with several situations that require anti-inflammatory action, such as cellulite, skin aging, acne, postoperative period, rosacea, dermatitis, bruises, psoriasis, etc.. In these cases, ozone therapy will play a significant role in remission or control of these affections through a potent anti-inflammatory effect.

\subsection{Antibacterial}

Unsaturated lipids are the main components of the cytoplasmic membrane present in bacteria. Ozone attacks the olefinic bonds (hydrocarbons) of the membranes, thus destroying the cell's functional capacity, which may even be sufficient to cause its death. Therefore, the bacterial membrane is the first site of ozone attack, and the death of bacteria occurs mainly with the rupture of the bacterial cell membrane [6] [25] [35].

Authors also reported that, during the ozone action, the phospholipids and lipoproteins of the bacterial cell membrane are oxidized. This disrupts the integrity of the cytoplasmic membrane, causing ozone to infiltrate into the microorganisms and oxidize glycoproteins and glycolipids, blocking their enzymatic function [4] [36].

Microorganisms susceptible to ozone include aerobic and anaerobic ones, such as Campylobacter, Clostridium, E. coli, Klebsiella, Mycobacterium, Pseudomonas, Salmonella, Staphylococcus, and Streptococcus. Authors found that ozone reduced the count of pseudomonas aeruginosa (a bacteria very resistant to antibiotics due to its double bacterial membrane) from 100,000/CFU to 350/CFU [37] [38].

Many people question whether ozone would also not be able to damage the body's cell membrane when attacking the lipid structure of the bacteria's membrane. The answer is no because according to some authors, ozone is safe for human cells because its germicidal action is based on transient oxidative stress (produced by ozone), lethal to microorganisms, as they have poor antioxidant defences. Some microorganisms lack some antioxidant enzymes (catalase and glutathione peroxidase) - present in human cells-These enzymes would be able to neutralize the oxidative action of ozone, which does not occur with bacteria [39] [40].

The antibacterial actions of ozone in aesthetics occur mainly in the treatment of acne and open wounds, especially ulcerations, and those associated with the postoperative period of plastic surgery, such as surgical dehiscence, scarring necrosis, infection in the suture points, etc. 


\subsection{Reduction of Oxidative Stress}

Oxidative Stress is characterized by the accumulation of reactive oxygen species (ROS), generated as by-products of physiological or exogenous stress factors (such as ionization by radiation) [33].

Reactive Oxygen Species (ROS) and Nitrogen Species (RNS) (constantly produced in aerobic organisms) are by-products of normal oxygen metabolism and include free radicals such as superoxide anion $\left(\mathrm{O}^{2-}\right)$, hydroxyl radical $(\mathrm{OH})$, singlet oxygen, and hydrogen peroxide $\left(\mathrm{H}_{2} \mathrm{O}_{2}\right)$ [41].

In small concentrations, ROS serves as cell signalling, contributing to important cell functions, such as cell proliferation, differentiation, and survival. High concentrations can lead to cell death by damaging cellular macromolecules such as DNA, proteins, and lipids. Cells have an antioxidant defence system; however, the excessive production of ROS can lead to cellular redox imbalance (imbalance between the action of ROS and cellular antioxidant capacity). Thus, the increased generation of ROS and/or dysfunction of the antioxidant system can lead to the condition of oxidative stress [42].

The therapeutic effectiveness of ozone therapy is due to the generation of controlled and moderate oxidative stress produced by the reactions of ozone with various biological components. Therefore, the effectiveness or toxicity of ozone may depend on the strength of the oxidative stress. Severe oxidative stress activates $\mathrm{NF} \kappa \mathrm{B}$, resulting in an inflammatory response and tissue damage due to the production of several substances (Cyclooxygenase-2, Prostaglandin-2, and cytokines). In contrast, moderate oxidative stress activates another nuclear transcription factor, Nrf2, which induces a beneficial antioxidant response to the body [43].

We recommend maintaining the redox balance, as according to some authors [29] [43], increased oxidative stress can generate important biological responses, including repercussions in clinical aesthetics. Here are some of them:

1) Oxidative stress directly modulates the differentiation of adipose cells (3T3L1 pre-adipocytes), which may increase adipogenesis of insulin-resistant adipocytes, and consequently generate overweight (obesity).

2) Fighting the effects of oxidative stress, the antioxidant NQO1 prevented and decreased the mass of abdominal adipose tissue (in rats).

3) Increased oxidative stress is associated with aging, both functional and aesthetic.

4) There may be inflammation (modulated by NFkB) leading to tissue damage.

Based on the above, we identified that ozone, with its natural oxidizing capacity, can generate mild or moderate oxidative stress. This causes the body to respond by increasing the action of Nrf2, and thus, generate some beneficial effects, such as Increased levels of direct antioxidants, such as reduced glutathione (GSH), carbon monoxide, and bilirubin; increased levels of enzymes that detoxify oxidants, such as catalase (CAT), superoxide dismutase (SOD), glutathione 
peroxidase (GPx), glutathione transferase (GSTr), NADPH-quinone oxidoreductase (NQO1), heme oxygenase-1 (HO-1) end-shock protein 70 (HSP70), etc.; inhibition of cytokine-mediated inflammation through induction of leukotriene B4 reductase; recognition, repair and removal of damaged proteins; and protection against oxidative stress-induced apoptosis [43].

Also, in this context, Nrf2 can modulate inflammation through the maintenance of redox homeostasis and results in a protection against neurodegenerative diseases, such as Alzheimer's and Parkinson's diseases (reversal of chronic oxidative stress) [33] [43].

Oxidative stress has been associated with the incidence of various aesthetic conditions, mainly localized fat (cellulite, dyschromia), dermo-epidermal aging, acne, etc. Therefore, we understand that increased oxidative stress is one of the major factors responsible for the cause and maintenance of several aesthetic dysfunctions. Thus, we see ozone therapy as a great ally for treatment [33] [44][49].

\subsection{Healing}

One of the main actions of ozone therapy is the enhancement of tissue wound repair. In the clinical evidence map, we found 13 reliable studies that prove the effectiveness of ozone therapy for complete wound closure [50].

Several physiological actions justify the potent action of ozone in tissue repair. As previously reported, ozone is capable of causing mild or moderate oxidative stress. For that, it relies on the generation of reactive oxygen species (ROS) [51], and according to some authors, ROS participates in the tissue repair process as follows: 1) Recruit lymphocytes to the wound site, to act in effective tissue repair; 2) Regulate blood vessel formation (angiogenesis) and optimal blood perfusion in the healing area; 3 ) Increase immunity through phagocytes that induce bacterial damage; 4) Produces bactericidal and bacteriostatic effect [52].

In general, ozone therapy can provide several benefits to accelerate tissue repair in various healing processes, including the release of growth factors such as fibroblasts, platelet derivatives, $\beta$ transformer and vascular endothelial; bactericidal action; anti-inflammatory action; increased granulation tissue and re-epithelialization; greater vascularization; reduction of local pain; decreased edema; stimulation of tissue contraction and reduction in the extension and depth of wounds [52]-[57].

The effectiveness of ozone in skin wounds in rats (after 7 and 14 days) resulted in an increase in myofibroblastic differentiation and microvessel density, an increase in the amount of fibroblast growth factor-2 (FGF2) in the epidermis and dermis, granulation tissue with fewer inflammatory cells and more fibroblasts and endothelial cells, and finally, more significant deposition of Type 1 collagen [58].

Cell cultures showed that ozone-induced fibroblast migration, indicating that it may aid wound healing [59]. Authors found that hydrogen peroxide $\left(\mathrm{H}_{2} \mathrm{O}_{2}\right)$ can potently induce the expression of vascular endothelial growth factor (VEGF) 
in human keratinocytes, stimulating wound healing [60].

Ozonized oil has become an effective tool to enhance tissue repair in various therapeutic situations, and it can be used with a procedure with gaseous ozone, or it can be used alone. However, there is still some divergence in the literature regarding the indication and/or effect of ozonized oils according to their peroxide index. For some authors [61], low (below $1000 \mathrm{mEq}$ ) and higher (above 3000 $\mathrm{mEq}$ ) peroxide indices delayed cutaneous wound healing; Travagli et al. [62] recommended a "medium" concentration (about $1500 \mathrm{mEq}$ ) for a more beneficial effect in accelerating wound closure. Other authors [63] found that higher levels of peroxide (1800 mEq, compared to $600 \mathrm{mEq}$ ) provided greater re-epithelialization of wounds in rats. However, when comparing ozonized and nonozonized aloe vera oil with gentamicin ointment, regarding the increase of the number of fibroblasts and collagen thickness after the tissue repair process, it was found that ozonized aloe vera oil generated a more significant increase in the number of fibroblasts and collagen thickness. It also increased wound closure speed but did not find significant differences between the peroxide indices of the oils tested $(600,1200$, and $1800 \mathrm{mEq})$ for the enhancement of tissue repair [64].

In our understanding, both gaseous ozone (injection and bags) and ozonized oil are excellent resources for increasing tissue repair processes, and this makes ozone therapy a powerful weapon to minimize complications and delay in tissue repair after surgery plastic, such as surgical dehiscence, tissue necrosis, suture stitch infections, etc., as well as wounds and skin lesions arising from various aesthetic procedures, such as cryolipolysis, peelings, epilatory lasers, etc.

\subsection{Lipolytic}

The interaction of ozone with fat tissue is well described in the literature, and therefore, we can expect good results in the treatment of aesthetic lipodystrophy.

One of the main effects attributed to ozone act on adipose tissue is lipid peroxidation, which is characterized by the oxidative degradation of lipids due to the high reactivity or oxidizing power of ozone [4] [43] [65].

Ozone can break down lipids into various derivatives, such as lipoperoxides, hydroperoxides, and low molecular weight lipid oxidation products (LOPs). Thus, ozone can interact with the carbon double bonds of polyunsaturated fatty acids in the lipid bilayer of cell membranes, dividing them (Ozolysis). This reduces their chains from long to short, making them hydrophilic; thus, these lipid chains are fragmented (phospholipids and lipoproteins) through oxidation, and this can damage cell walls that are made up of phospholipids and lipoproteins [11] [15] [66].

According to some authors, lipid peroxidation produces oxidative modifications that cause changes in the physicochemical properties of cell membranes, such as increased membrane permeability and changes in fluidity generate "expulsion" of intracellular fluid, with risk of rupture of cell membranes (oxidation of phospholipids and lipoproteins), and lysis of organelles, with consequent 
adipocyte cell death [66] [67].

Adipocytes were exposed to ozone for $2 \mathrm{~h}, 24 \mathrm{~h}$, and $48 \mathrm{~h}$, with concentrations of $10 \mu \mathrm{g}, 20 \mu \mathrm{g}$, and $100 \mu \mathrm{g}$. The authors found that at a concentration of $20 \mu \mathrm{g}$, after $24 \mathrm{~h}$, small lipid droplets were sprouting from the surface of the adipocyte, and $48 \mathrm{~h}$ later, they identified adipocytes with slight depressions, wrinkled, and many lipid droplets sprouting. At the concentration of $100 \mu \mathrm{g}$, adipocytes suffered evident necrosis, with accentuated lipid loss and barely recognizable organelles. The authors did not verify the incidence of apoptosis [68].

In one of our experiments, we injected the oxygen-ozone gas mixture $(5 \mathrm{ml}$ at each point, with a concentration of $15 \mu \mathrm{g}$ ) directly into the subcutaneous adipose tissue. After immunohistochemical analysis (analysis of the expression of the CD68 marker-macrophages), we identified the presence of macrophages in the treated tissue (Figure 1) which, according to some authors [69] has been associated to degeneration of different tissues, including the hypodermic adipose tissue. Therefore, the accumulation of macrophages in the adipose tissue can be considered the main justification for the death of adipocytes. Thus, our findings corroborate the reports of some authors [66] [67], who describe the use of ozone as an efficient mechanism of damage to the adipocyte membrane, which can lead to cell death due to post-application lipid peroxidation of local ozone.

In addition, we also identified the occurrence of localized lipolysis with the use of ozone in the treated fat tissue (Figure 1). Although the effect of lipolysis through ozone therapy is not yet well described in the literature [70], it mentioned the effect of lipolysis with ozone in the treatment of a lipoma. There is no doubt that ozone acts efficiently as a lipolytic agent. Once ozone dissolves in interstitial water, lipids are the preferred substrate of action and are broken down into a series of derivatives arising from lipid peroxidation, which could justify the effect of local lipolysis [13]. The ozone activates the circulation in all tissues, promoting the release of oxygen to them, thus providing several effects, and among them, the induction of lipolysis [11].

The graph on lipolysis shows the increase in this process in the area treated with ozone therapy. The second graph demonstrates the presence of CD68+ macrophage markers on the treated side, which likely demonstrates adipose cell lysis and the phagocytosis process.

We understand that ozone, especially when injected locally in the subcutaneous fat tissue, can oxidize the lipid components of the cell membrane, leading to adipocyte death and consequent reduction of unsightly localized fat also enhanced by the stimulation of local lipolysis.

\section{Ozonetherapy and Its Applicability in Aesthetic Dysfunctions}

Currently, we have identified several aesthetic affections with great potential for total or partial resolution with the use of ozone therapy. We will describe below some forms of treatment for some conditions, highlighting some protocols used in dosimetry and techniques for local, systemic, or associated application. 

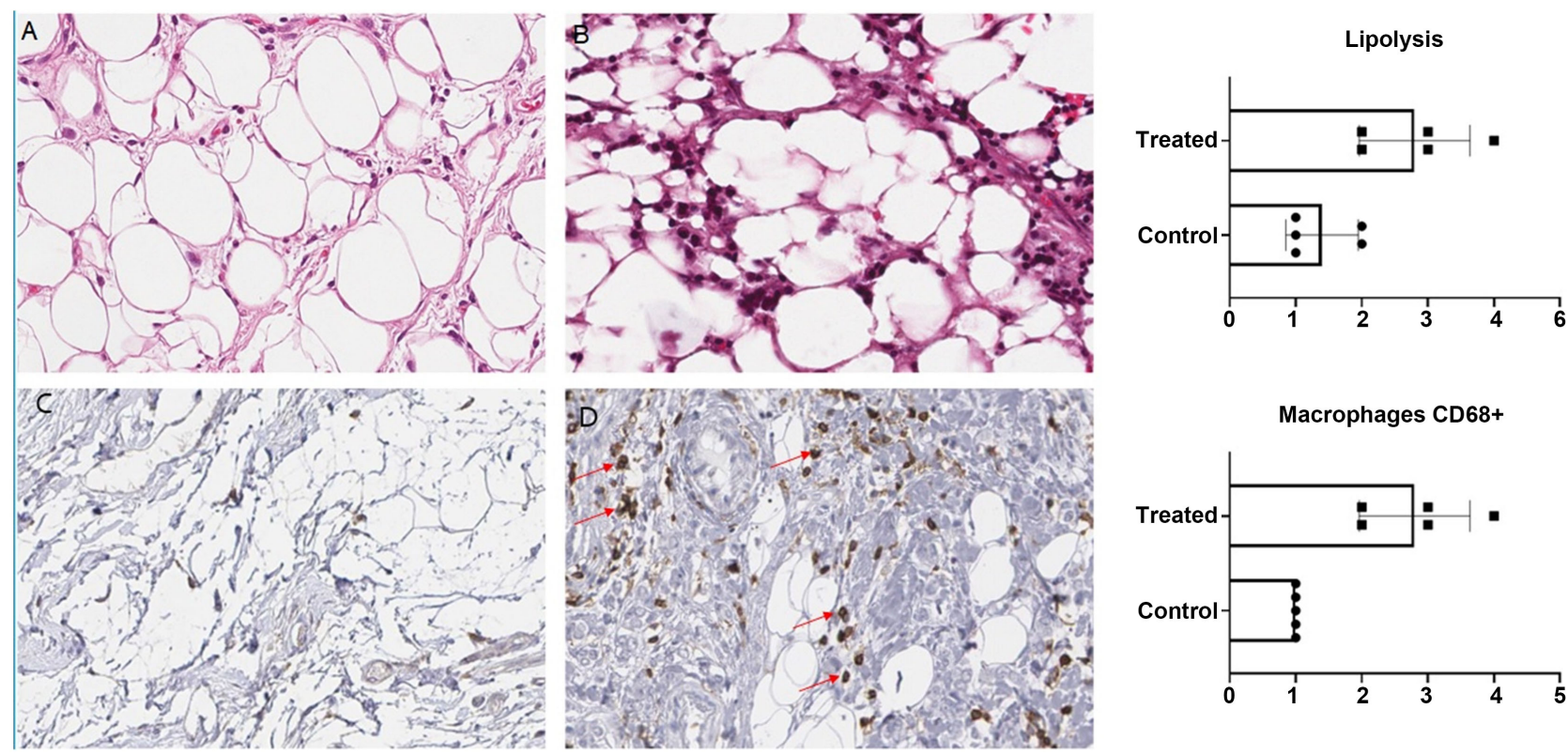

Figure 1. Effects on adipose cells after application of ozone therapy. (A) Fat cells before treatment; (B) Identification of lipolysis in treated adipose tissue; (C) Absence of macrophages (D) Marked presence of macrophages (CD68 marker) in the fatty tissue treated with ozone therapy. (Source: Authors).

\subsection{Cellulite}

Currently, cellulitis is perhaps one of the most described affections in the literature with indication for treatment with ozone therapy.

The general clinical picture of cellulite is closely associated with the therapeutic actions of ozone. The adipose tissue affected by cellulite has a high degree of oxidative stress [49]; In addition, authors have reported that there is also a correlation between Reactive Oxygen Species (ROS), oxidative stress, and fibrotic processes in cellulite skin, including increasing stimulation of fibroblasts [48] [49]. The "excess" of subcutaneous fat (subdermal cellulite) is also common, especially in more advanced degrees of cellulite; there may also be a stagnation of the microcirculation (paniculosis), which increases the passage of albumin, fibrinogen, and immunoglobulins through the vessels, giving rise to and/or aggravating the cellulitic condition [14] [49].

Based on the above, we will describe below some justifications for the use of ozone to treat cellulite.

Ozone therapy can activate Nrf2 (Master regulator of the body's antioxidant response), decreasing local or systemic oxidative stress, thus providing a delaying or remitting effect of the condition [33]. In addition, ozone can exert an anti-inflammatory action, reducing the production of pro-inflammatory cytokines, immunoglobulins, and inflammatory mediators that are often associated with cellulite [71] [72]. Regarding cellulite, through lipid oxidation in the double carbon bonds of fatty acids (Polyunsaturated) of the adipocyte membrane, ozone can cause damage to the cell walls of adipocytes, causing lysis and, therefore, reducing the subcutaneous fat tissue (cellulite) [11] [15] [66]. The lipolysis effect 
can enhance this decrease, as verified in our experiments.

In addition to these effects, the use of ozone can also activate microcirculation [4] and is capable of eliminating stagnant interstitial fluids (chronic cellulitic edema) due to its hydrophobic effect [15]. Finally, the application of ozone in the subdermal fatty tissue can increase the elasticity and tone of the skin, as well as reduce sagging. This is important in cases of flaccid cellulite treatment, where there is an impairment of the skin tone [47].

In Table 1, we describe the protocols commonly suggested by some authors to use ozone therapy for the treatment of cellulite. Despite these reports, in our clinical practice, we use concentrations that can reach $10 \mu \mathrm{g} / \mathrm{ml}$ (depending on the pain reported by the clients) (Figure 2), and we usually associate local ozone injection with rectal insufflation (Figure 3). In cases of flaccid cellulite, we also use gluteal macro-vents (Pump-up) with the addition of ozone inside (Figure 4). Electro thermotherapeutic resources can also be associated with radiofrequency, tecartherapy, shock waves, ultrasound, carboxytherapy, vacuum therapy, and others. Remember that the sequence of use of these resources must comply with biophysical criteria and common sense. We did not find any mention in the literature about the association of electro thermotherapy resources with ozone to treat cellulite. The use of ozonized or non-ozonized cosmetics at home can also be a good adjuvant to enhance cellulite treatment results.

\subsection{Localized Fat}

Some justifications allow the use of ozone to treat localized fat. As previously described in the treatment of cellulitic subcutaneous fat, ozone will act in the same way in the deeper fat (subcutaneous fat reserve) because due to its reactivity, ozone will trigger lipid peroxidation causing cell lysis of adipocytes [43] [66] [67], in addition to stimulating lipolysis in the fat tissue [11] [13] [70].

Table 1. Published protocols for the treatment of ozone therapy in cellulite.

\begin{tabular}{|c|c|c|c|c|c|}
\hline Concentration & $\begin{array}{l}\text { O3 volume by } \\
\text { points }\end{array}$ & $\begin{array}{l}\text { Total gas volume } \\
\text { per session }\end{array}$ & Frequency & Associations & Source \\
\hline - 1 to $5 \mu \mathrm{g} / \mathrm{ml}$ & 3 to $5 \mathrm{ml}$ & $200 \mathrm{ml}$ & 2 times/week & -- & $\begin{array}{l}\text { Galoforo et al., } \\
2002[15]\end{array}$ \\
\hline$-5 \mu \mathrm{g} / \mathrm{ml}$ & $\begin{array}{l}10 \mathrm{ml} \text { for an } \\
\text { area of } 5 \mathrm{~cm}\end{array}$ & -- & $\begin{array}{l}1 \text { to } 2 \\
\text { times/week }\end{array}$ & -- & Sirito, 2006 [12] \\
\hline $\begin{array}{l}\text { - } 2 \text { to } 4 \mu \mathrm{g} / \mathrm{ml} \\
\text { - Hard cellulite: } 2 \mu \mathrm{g} / \mathrm{ml} \\
\text { - Flaccid Cellulite: } 1.5 \text { to } 2.6 \mu \mathrm{g} / \mathrm{ml} \text {; } \\
\text { - Edematous Cellulite: } 3 \text { to } 4 \mu \mathrm{g} / \mathrm{ml} \text {. }\end{array}$ & 1 to $2 \mathrm{ml}$ & $100 \mathrm{ml}$ & 1 time/week & $\begin{array}{l}\text { Massage with ozonized } \\
\text { oil }\end{array}$ & Bocci, 2010 [13] \\
\hline $\begin{array}{l}\text { - } 1 \text { to } 5 \mu \mathrm{g} \\
\text { - Light: } 1.5 \text { to } 2.5 \mu \mathrm{g} / \mathrm{ml} \text {; } \\
\text { - Moderate: } 2 \text { to } 3 \mu \mathrm{g} / \mathrm{ml} \text {; } \\
\text { - Strong: } 4 \text { to } 5 \mu \mathrm{g} / \mathrm{ml}\end{array}$ & 5 to $7 \mathrm{ml}$ & $200 \mathrm{ml}$ & $\begin{array}{l}2 \text { to } 3 \\
\text { times/week }\end{array}$ & $\begin{array}{l}\text {-Rectal insufflation: } \\
10 \text { to } 20 \mu \mathrm{g} / \mathrm{ml} \text {; } \\
1 \text { to } 2 \text { times/week } \\
\text { - Manual lymphatic } \\
\text { drainage with ozonized } \\
\text { oil; } 1 \text { to } 2 \text { times/week }\end{array}$ & $\begin{array}{l}\text { Cuccio \& Franzini, } \\
2016[14]\end{array}$ \\
\hline
\end{tabular}




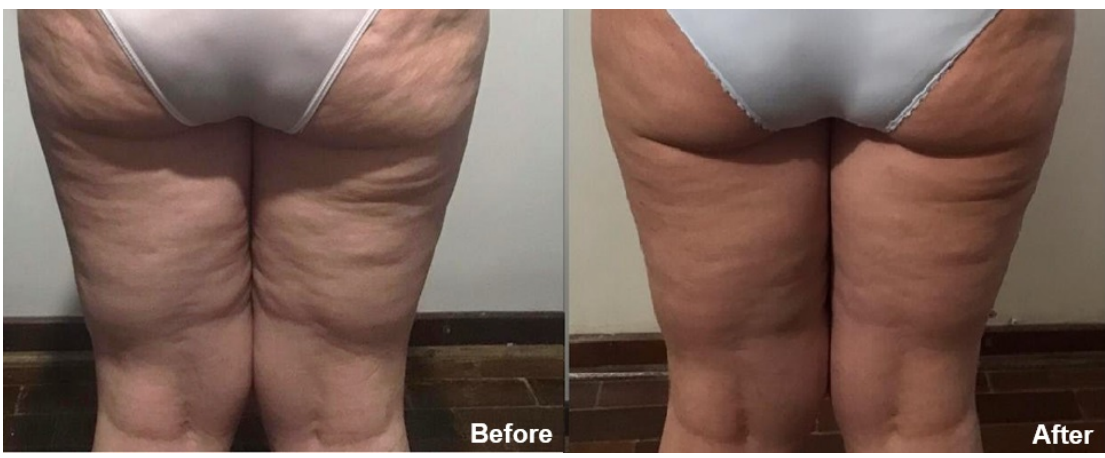

Figure 2. Results of cellulite treatment with ozone therapy using concentration: $10 \mu \mathrm{g}$, injection of $5 \mathrm{ml}$ in each point, twice a week, and a total of 12 treatment sessions. (Kindly provided by Joara Defani-Marilia-SP/Brazil).
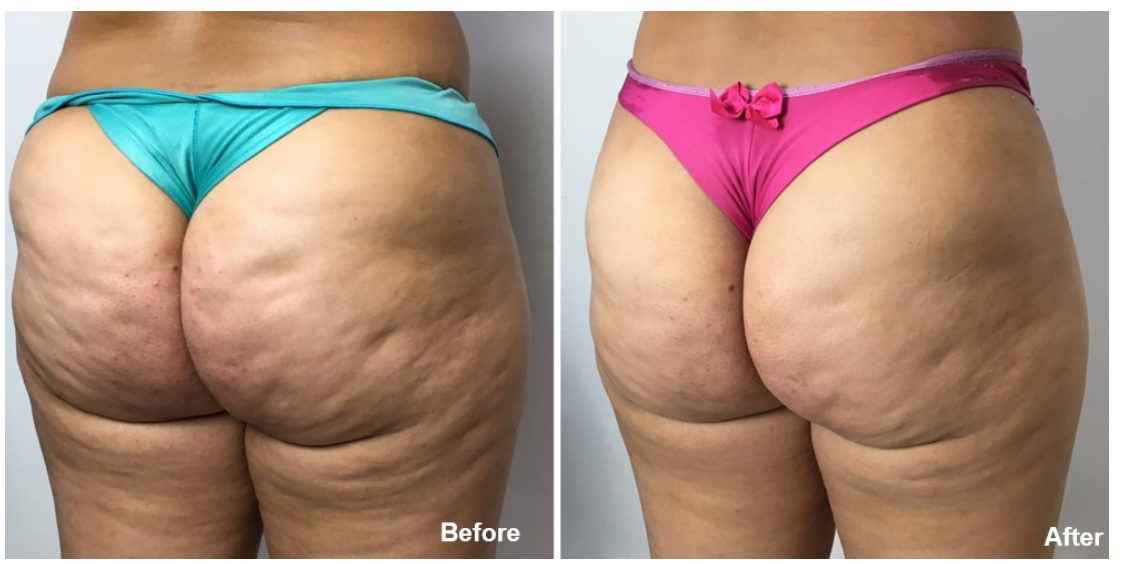

Figure 3. Cellulite treatment with ozone therapy using a concentration of $10 \mu \mathrm{g}$, injection of $5 \mathrm{ml}$ at each point, once a week, rectal insufflation, and a total of 6 treatment sessions. (Kindly provided by Cassiane Costa (Bauru-SP/Brazil).

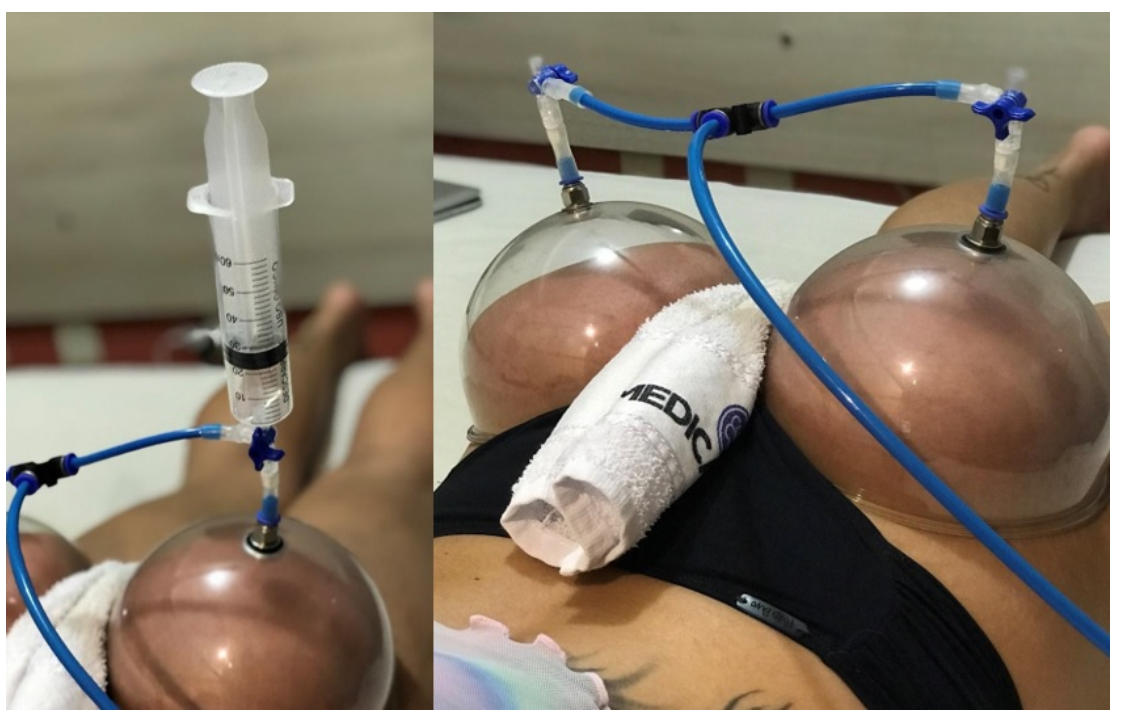

Figure 4. Use of macro suction cups ("Pump-up") in the treatment of flaccid cellulite.

Ozone would also have the ability to interfere with overall body weight, thus providing some weight loss. The activation of Nrf2 also inhibited the differentia- 
tion capacity of 3T3L1 cells (pre-adipocytes) and in obesity [51]. The presence of Nrf2 can protect against obesity [30]. Therefore, we always recommend the association of systemic ozone with local application in the treatment of localized fat, as the antioxidant action of ozone, through the generation of mild oxidative stress, becomes a great adjuvant for reducing large fat deposits. The associated ozone therapy (rectal insufflation with 20 to $40 \mu \mathrm{g} / \mathrm{ml}$ and 150 to $300 \mathrm{ml}$ of O3) to a group of volunteers who were dieting, compared them with another group that was not. Ozone potentiated the decrease in weight and measurements associated with diet, generating a significant difference in body weight, waist circumference, and BMI (Body Mass Index) [73].

Currently, ozone therapy protocols for the treatment of localized fat vary in the literature and the clinical practice of many professionals. The treatment of a patient with a lipoma on the back using a $4 \mu \mathrm{g} / \mathrm{ml}$ concentration and $10 \mathrm{ml}$ of gas at each injection point twice a week. In our clinical practice, we currently use and recommend the injection of ozone gas at $15 \mu \mathrm{g} / \mathrm{ml}$ and $5 \mathrm{ml}$ per point [11]. However, a Russian study [47] revealed another way to use the concentration and volume of gas, modifying the total dosimetry at each treatment session. The protocol consisted of increasing the concentrations and injected volumes over 10 treatment sessions, starting with a concentration of $20 \mu \mathrm{g} / \mathrm{ml}$ and $250 \mathrm{ml}$ volume per total treatment area, and ending with $50 \mu \mathrm{g} / \mathrm{ml}$ and $600 \mathrm{ml}$, in some cases. The study revealed that the therapeutic responses are better when we only vary the volumes, keeping the same concentration until the end of the treatment (Group 4) (Table 2).

Note that in groups 3 and 4, there was a variation in the volume introduced throughout the treatment sessions, and this variation also occurred with the concentration of ozone during the sessions in the groups 2 and 3 (Source: Poliychuk, 2010 [47]).

In our clinical practice, we find in the market, and we commonly use in the treatment of localized fat concentrations ranging from 10 to $15 \mu \mathrm{g} / \mathrm{ml}$ with $5 \mathrm{ml}$ (or more) of ozone at each gas injection point, obtaining excellent therapeutic results of association or non-systemic application, such as rectal insufflation (Figure 5).

Table 2. Russian treatment scheme with ozone therapy for the treatment of localized fat.

\begin{tabular}{|c|c|c|c|}
\hline \multirow{2}{*}{ Group } & \multirow{2}{*}{$\begin{array}{l}\text { Number of } \\
\text { patients }\end{array}$} & \multicolumn{2}{|l|}{ Treatment program: 10 sessions $-2-3$ times a week. } \\
\hline & & Ozone concentration $(\mu \mathrm{g} / \mathrm{ml})$ & Mix volume $(\mathrm{ml})$ \\
\hline 1 & 39 & 20 (no changes) & 250 (no changes) \\
\hline 2 & 30 & $\begin{array}{l}\text { One concentration per session: } 20,25,25,32,32,32 \text {, } \\
40,40,50,50\end{array}$ & 250 (no changes) \\
\hline 3 & 30 & $\begin{array}{l}\text { One concentration per session: } 20,20,20,25,32,32 \text {, } \\
40,40,50,50\end{array}$ & $\begin{array}{l}\text { One volume per session: } 250,250,250,250 \text {, } \\
360,360,360,360,480,600\end{array}$ \\
\hline 4 & 42 & 20 (no changes) & $\begin{array}{l}\text { One volume per session: } 250,360,360,360 \text {, } \\
420,420,480,480,600,600\end{array}$ \\
\hline
\end{tabular}




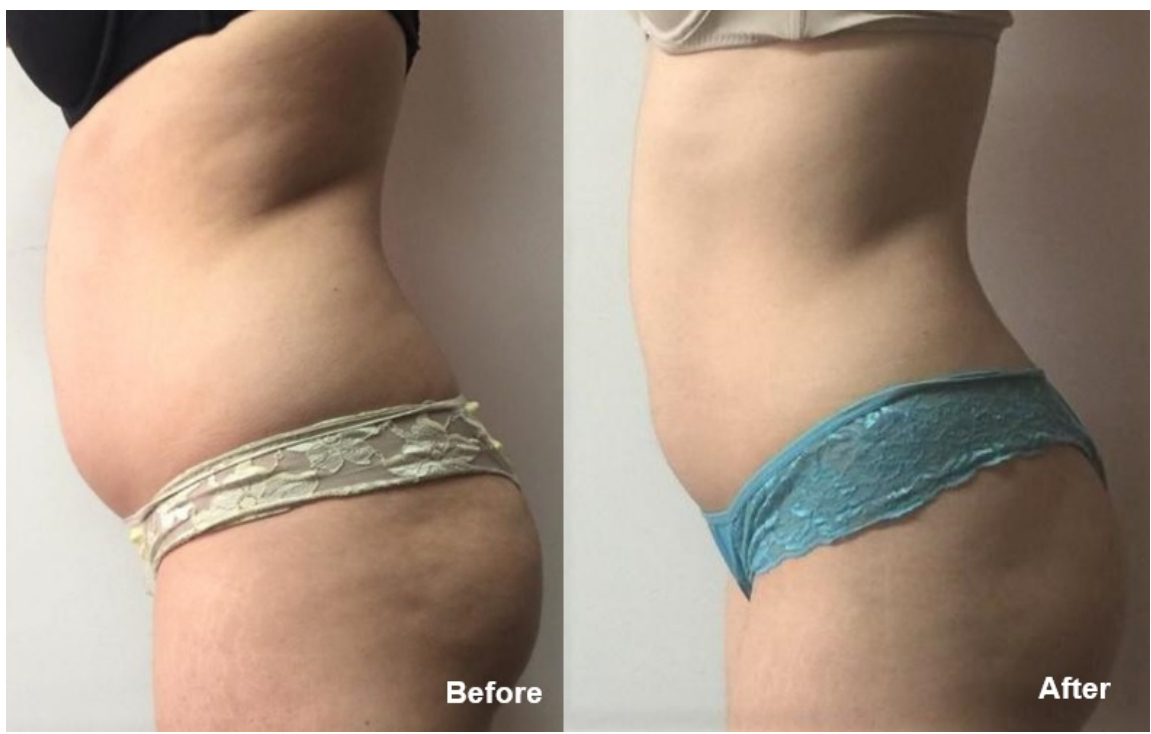

Figure 5. Treatment of localized fat in the abdomen with ozone therapy using concentration: $10 \mu \mathrm{g} / \mathrm{ml}$ (total volume of $180 \mathrm{ml}$ ), once a week, rectal insufflation with $20 \mu \mathrm{g} / \mathrm{ml}$ and $180 \mathrm{ml}$ of volume, and a total of 10 treatment sessions. (Kindly provided by: Juliana Tiradentes (Itaperuna-RJ/Brazil).

As we consider the Russian protocol [47] as aggressive and quite painful but considering the good result achieved in the study, we are currently also guiding an adaptation to these doses using concentrations between 10 and $20 \mu \mathrm{g} / \mathrm{ml}$ (according to the sensitivity threshold) and varying the injected volume at each point from 3 to $10 \mathrm{ml}$, over ten treatment sessions in the treatment of localized fat.

Another way to treat localized fat and cellulite, stretch marks, scars, alopecia, etc., is to apply the ozone directly from the equipment to the target area without using syringes, but using a silicone hose. In Brazil, this methodology is called the "Free Flow" Mode or popularly the Carboxi Mode (because it is similar to the way Carboxytherapy is used, without syringes). This form of ozone injection is based on the reports of some authors [65] [74] [75] [76] who described the use of ozone without syringes but using a urethral probe, gauge 12 to 14 , to take the gas from the equipment directly to the vaginal or rectal cavity, infusing about 50 to 500 millilitres of the ozone-oxygen mixture for up to a few minutes (depending on the desired volume).

At the beginning of the implementation of this methodology, there was some resistance from some professionals for not understanding the correct form of use and for thinking that there would be risks for the client and the professional due to a possible accidental emission of ozone in the service environment, thus as, and a possible "overdose" of injected ozone. Nevertheless, as soon as we suggested the addition of equipment to measure and control the concentration of ozone in the ambient air to prevent the place of care from having the ppm of ozone increased to the point of causing harm to the health of those who were there, this was no longer a taboo. Finally, we describe how to calculate the total 
dose of ozone injected during care using ozone therapy in "Free Flow" mode for the treatment of localized fat, and we attest to the safety and effectiveness of the method.

We also use a lot of the association of ozone therapy with electro thermotherapeutic resources to treat localized adiposity. We currently associate local ozone injection with various equipment, such as radiofrequency or tecartherapy, cryolipolysis, carboxytherapy, electrolypolysis, ultracavitation, ultrasound, etc excellent results without interferences or adverse effects in our clinical practice (Figure 6 and Figure 7).

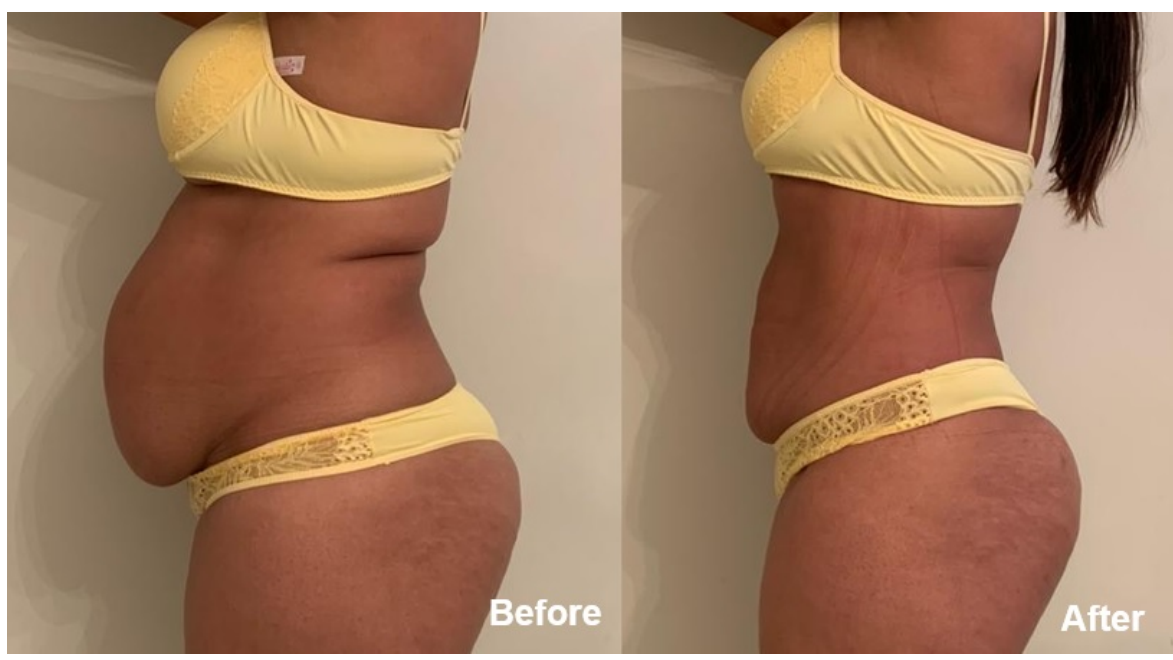

Figure 6. Treatment of localized fat in the abdomen with ozone therapy and associations: 1 cryolipolysis session; after 4 days, Carboxytherapy ( 5 sessions, $2 \times$ week); then local ozone therapy (15 $\mu \mathrm{g} / 3$ to $5 \mathrm{ml}$ per point) ( 5 sessions, $2 \mathrm{x}$ week). (Kindly provided by Gleicy Santos (Mirasol D’Oeste-MT).

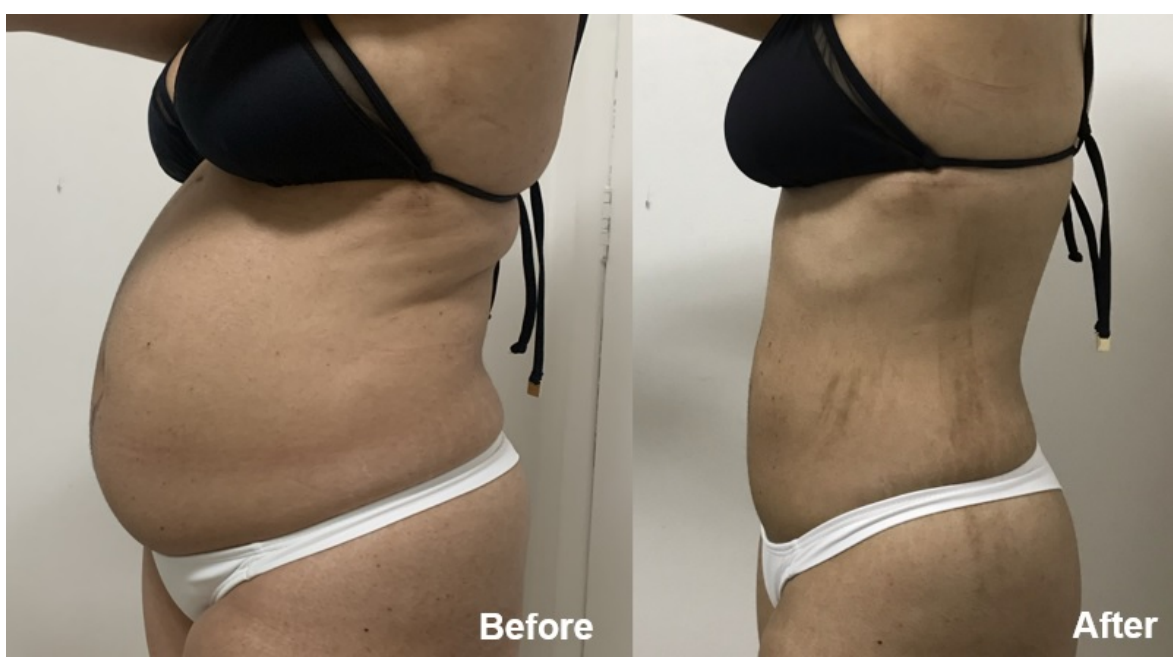

Figure 7. Treatment of localized fat in the abdomen with ozone therapy and associations: 4 sessions of rectal insufflation before using plate cryolipolysis; 48 hours after the treatment with cryolipolysis, 6 more sessions of rectal ozone therapy (2 times a week; concentration of 20 to $30 \mu \mathrm{g}$, and volume of 240 to $300 \mathrm{ml}$;); totalled 6 sessions. (Kindly provided by Janaína Fantoni (Joinvile-SC). 
Finally, we also used the injection of ozonized saline solution in the subcutaneous fat tissue to reduce it, and we have obtained excellent results (Figure 8). The ozonisation of saline solution is based on the Madrid declaration with low doses, i.e. $1.1 \mu \mathrm{g}$ for each kilogram of body weight [77], however, in our practice, we ozonize $250 \mathrm{ml}$ of saline solution with $60 \mu \mathrm{g}$ for 10 minutes, and we injected 5 $\mathrm{ml}$ of the ozonized saline solution in each point. In some cases, we immediately use ultrasound, ultracavitation, or shock waves to perform non-aspiration hydrolipoclasis, obtaining excellent results.

\subsection{Rejuvenation and Tissue Flaccidity}

A low but chronic level of inflammation (when there are no real exogenous or endogenous causes) is a common feature of aging or some age-related illnesses [33]. Therefore, the Nuclear Factor $\kappa \mathrm{B}(\mathrm{NF}-\kappa \mathrm{B})$ was the transcription factor most associated with aging [78].

As already mentioned, Nrf2 can modulate inflammation through the maintenance of redox homeostasis (balancing the actions of ROS and the cellular antioxidant capacity) and the suppression of pro-inflammatory genes, directly or through the inhibition of NF- $\kappa \mathrm{B}$ [31] [32] [33]. Thus, activation of Nrf2 through ozone therapy [34] [79] can inhibit the NF $\kappa$ B pathway and activate antioxidant enzymes, decreasing the action of inflammatory cytokines. Therefore, it is understood that the therapeutic modalities of systemic ozone therapy, such as rectal insufflation, autohemotherapy, and intravenous injection of ozonized saline solution can increase the expression of $\mathrm{Nrf2}$, decrease oxidative stress, and therefore delay the signs of aging, including in the skin. Therefore, due to our clinical practice, we recommend including systemic ozone therapy in aesthetic treatments for rejuvenation to support the local treatment and thus enhance the results, especially in the medium and long term [17] [35] [46] [80].

Associated with aging, we usually face changes in the dermo-epidermal structure of the skin, especially wrinkles, sagging, and elastosis. A large part of this problem resides in the production and maintenance deficiency if collagen and elastin in the skin [81]. The subcutaneous injection of ozone, with a concentration of 1 to $2 \mu \mathrm{g}$, once every 7 to 10 days, was able to benefit the skin through some effects: it improved the structural organization of the dermis, decreased deformation fibrotic, decreased the excessive accumulation of interstitial fluid in the dermis, produced a significant increase in the thickness of the dermis $(3.55 \%)$ (thickening of the epidermal and dermal layers), increased the general elasticity of the skin, restoring the smoothness of the skin micro-relief, increased skin microcirculation by 2.2 times, increased skin moisture by $20.11 \%$ (the effect remained for about 2 to 6 months), normalized trans epidermal water loss and the skin's barrier function, in addition to normalizing the $\mathrm{pH}$ of the skin (approaching pH 5.5) [82].

Still, on the action of ozone on skin components, authors [16] mentioned that the intradermal injection of ozone can stimulate the action of fibroblasts and 


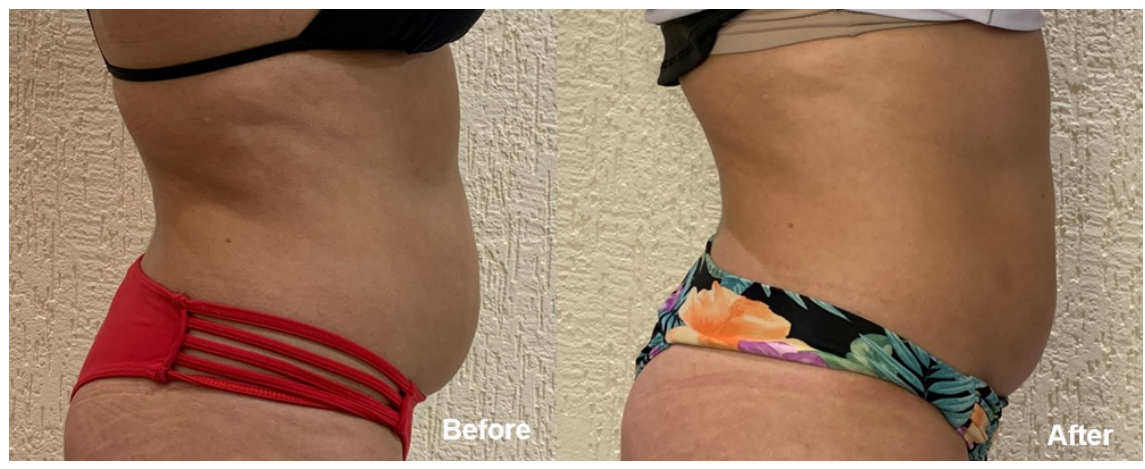

Figure 8. Treatment of localized fat in the abdomen with local injection of ozonized saline solution: 10 sessions ( 2 times a week, volume of $5 \mathrm{ml}$ at each injection point; saline solution $(250 \mathrm{ml})$ was ozonized with $60 \mu \mathrm{g}$ for 10 minutes.

thus produce collagen, reducing fine wrinkles. Other authors [83] found an increase in type 1 collagen ( 1.6 times) in gingival cell cultures by exposing them to an ozonized gel $(0.5 \mathrm{ppm})$. Local ozone therapy was mentioned as an excellent resource for the bio stimulation of collagen in the skin [84]. The authors reported a case of collagen bio stimulation using intradermal ozone injections on the face and neck, in which they bio stimulated the skin using ozone, once a week, at a concentration of $5 \mu \mathrm{g}$ in the first two treatment sessions and increased to $10 \mu \mathrm{g}$ ( $3 \mathrm{rd}$ and 4 th sessions) and $15 \mu \mathrm{g}$ (5th and 6th sessions) in the following sessions. At the end of each session, they wore a compressive mask moistened with ozonized water $(60 \mu \mathrm{g})$ for 10 minutes. As a result of the treatment, the authors found a reduction or elimination of wrinkles, an improvement in the dermal turgor on the face and neck, and the reduction of spots on the skin on the face.

In our clinical practice, we use some ozone injection techniques for the treatment of aesthetic dysfunctions concentrated in the skin, among which are intradermal with retro injection, intradermal with pleating (the gas is more concentrated in the subdermal region), the traditional intradermal, and the mesoepidermal (more superficial), all with good therapeutic results. According to our clinical practice, the concentration of the oxygen-ozone mixture, depending on the sensitivity threshold, the non-aesthetic condition, and the therapeutic objective, we usually use 8 to $15 \mu \mathrm{g}$ for most affections. Regarding periodicity, despite some reports indicating the use of ozone on the skin from 7 to 10 days apart [82] [84], in our day-to-day care, we perform the treatment with intervals 15 to 21 days apart, to ensure a better evaluation between sessions, waiting for a more consistent result, considering the possibility of greater collagen deposition/maturity.

In addition to aspects related to rejuvenation, we emphasize that the effects of ozone therapy on the skin also influence cases where it is sought to reduce only sagging skin, including the body. In this case, ozone is an important ally for the treatment, producing the same effects obtained in rejuvenation.

In Figure 9 through Figure 10 we show some results of the use of ozone in skin-related aesthetic dysfunctions. 


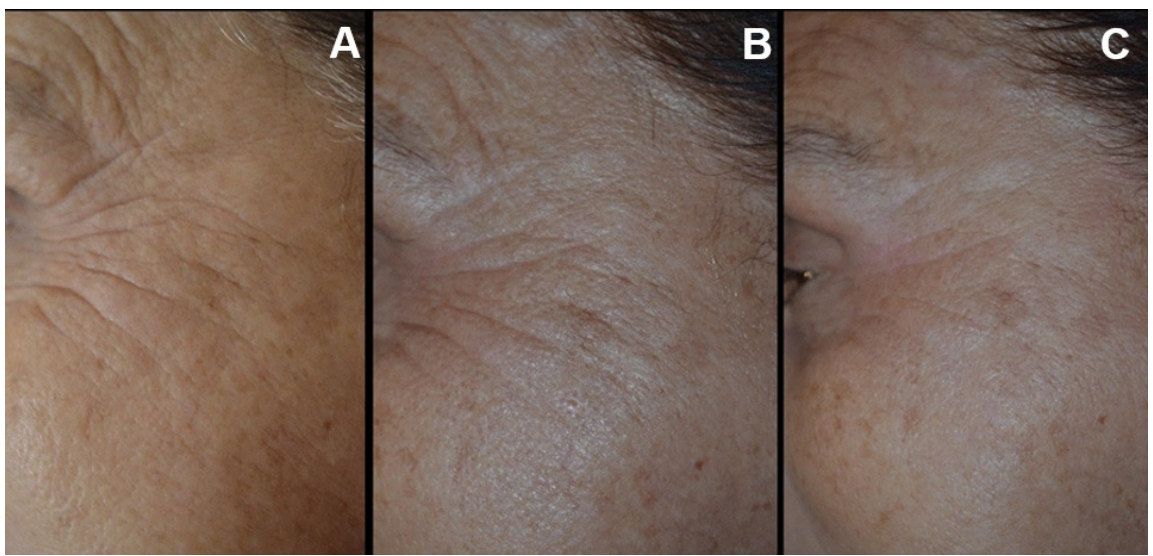

Figure 9. Rejuvenation of the peri orbicular region of the eyes: 8 sessions ( 1 time every 20 days, $1 \mathrm{ml}$ volume at each injection point; $15 \mu \mathrm{g}$ concentration; intradermal technique with retro injection). (A) Before treatment; (B) 4 sessions; and (C) After treatment.

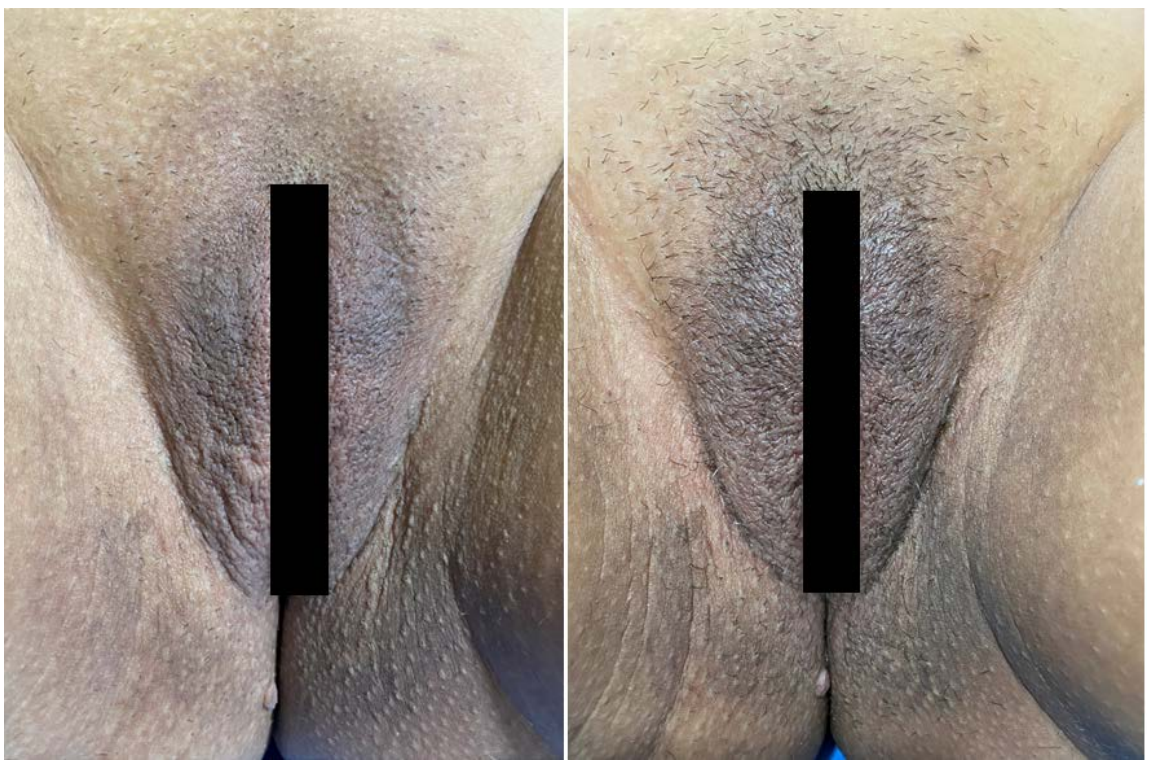

Figure 10. Rejuvenation of the intimate female area: 5 sessions ( 1 time every 15 days, volume of 1 to $2 \mathrm{ml}$ at each injection point; concentration of $10 \mu \mathrm{g}$; intradermal technique).

Ozone therapy for the treatment of skin disorders and other aesthetic conditions mentioned above can also be associated with other therapeutic resources to optimize results, whether used in the same session or not. Among the most used joint resources applied to the same treatment session, we have the radiofrequency, which we suggest using prior to the ozone injection to avoid any influence of the local temperature increase after the gas injection. With this, perhaps to reduce its therapeutic action (although we did not find studies on this association, this is our understanding); LASER or LED, which can enhance collagen production; and cosmetics, mainly ozonized. Furthermore, among the resources that can be associated (on different days) with the ozone therapy session are $\mathrm{Mi}$ croneedling, Intradermotherapy, Plasma Jet, etc., which can be used interspersing ozone therapy sessions for 7,21 , or 30 days, depending on the resource used 
and of the intended therapeutic goal.

\subsection{Pre- and Post-Plastic Surgeries}

Ozone therapy has provided great help to plastic surgeons, both before and after operative procedures, especially for resolving complications in surgical flaps.

Although it is not common, the referral of patients before surgery is of great importance when the objective is to prepare the tissue for postoperative recovery. Ozone therapy can improve surgical wound healing by performing skin preparation at the incision site [85]. In the postoperative period, ozone can be used for various clinical situations, especially for surgical dehiscence (Figure 11) and residual bruises/ecchymosis, delayed tissue repair in scars, fat or residual flaccidity from liposuction, postoperative infection, etc. [86]. Some authors [68] have suggested that adipocytes extracted for autologous transplantation would be better preserved, with more prolonged survival, for grafting in patients undergoing autologous fat transplantation if they were exposed to ozone at a concentration of $10 \mu \mathrm{g} / \mathrm{ml}$. Based on this report, this type of pre-grafting procedure using ozone is already being performed by plastic surgeons in Brazil, with excellent postoperative clinical evolution.

After a surgical procedure, inflammation generates oxidative stress, and both were the leading causes of postoperative scar adhesion in the peritoneum of rats. According to the authors, ozone (used soon after surgery) decreases oxidative stress (stimulates endogenous superoxy dismutase and glutathione peroxidase), decreases inflammation, and, thus, the formation of postoperative peritoneal adhesion [87].

Also, in this context, the postoperative period can generate one of the most challenging sequels to treat, which brings many inconveniences for those affected, post-liposuction fibrosis. In our clinical practice, ozone has produced excellent results for the resolution of this type of affection. The understanding is that peroxides produced by ozone, including those contained in ozonized oil, can increase the production of some cytokines by stimulating fibroblast cells to activate a phagocytic action of excessive collagen fibres in the connective tissue, including fibrous [88].

Based on these effects and our clinical practice, we recommend the use of ozone in the preoperative period of plastic surgery to reduce oxidative stress (rectal insufflation) to accelerate recovery in the immediate convalescence period after the surgical procedure, and to prepare the skin which will be excised during surgery to have a better quality of post-surgical tissue repair. As for the postoperative period, currently, we have worked with ozone therapy much more on scarring sequelae, such as dehiscence (Figure 11), residual fibrosis, infection, and necrosis, basically using local gas injection ( 5 to $10 \mu \mathrm{g} / \mathrm{ml}$ ), the bag or suction cup (Figure 12), rectal insufflation or ozonized auto-hemotherapy, and ozonized oil. 


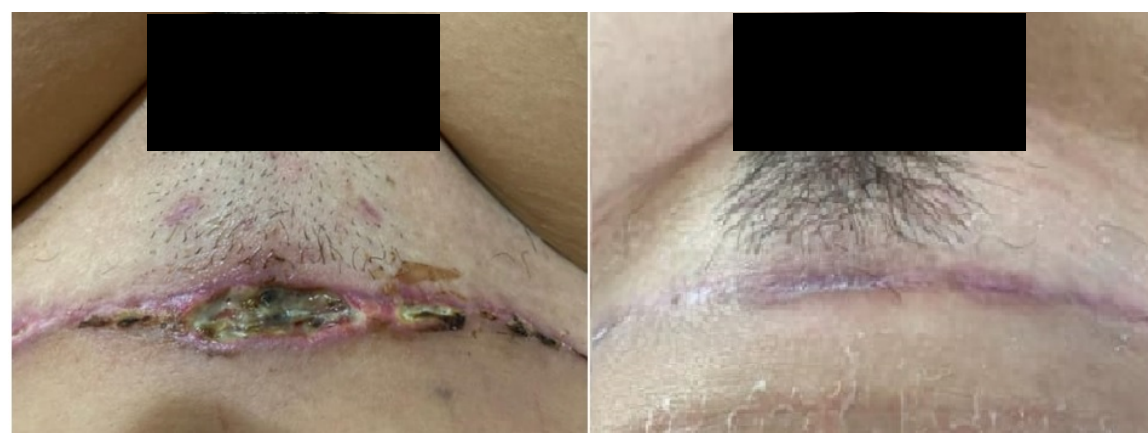

Figure 11. Post-surgical dehiscence accompanied by infection 12 days after surgery. She was treated with 6 of ozone-bag sessions ( $60 \mu \mathrm{g}, 20 \mathrm{~min}$ ) (twice a week) and tissue release massage. (Kindly provided by Adriana Bastos-Belo Horizonte-MG).
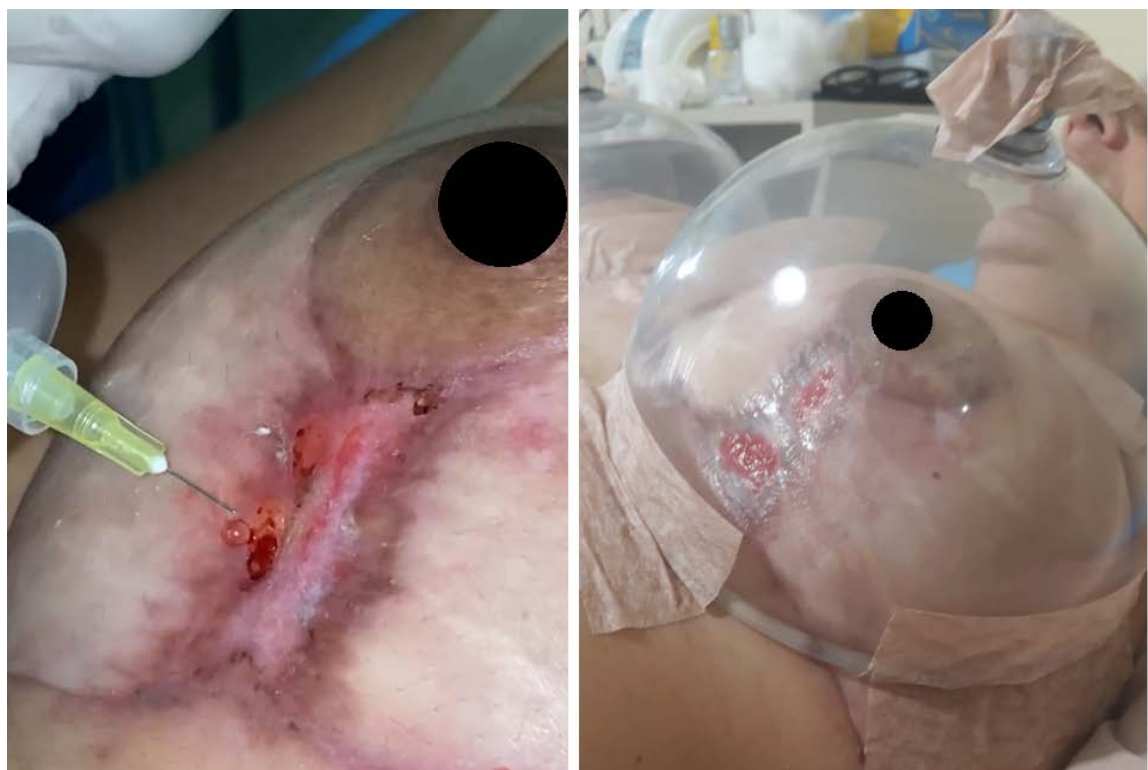

Figure 12. Treatment of post-mastopexy dehiscence with local injection of ozone and macro pump ("Pump-up") to create a "compartment" to contain the ozone for disinfection and stimulation of tissue repair on the surface of the scar lesion. (Kindly provided by Fabiana Gonçalves-Rio de Janeiro-RJ).

\subsection{Stretch Marks}

Although we have not found specific studies on the use of ozone directly on stretch marks, we are obtaining excellent results with the use of this gas in the treatment of this type of condition. In our understanding, the action of skin perforations with the needle for ozone injection and the very local action of the gas in streaks provides an effect similar to what occurs when treating flaccid and/or aged skin [16] [83] [84], based mainly on stimulation of the action of fibroblasts for bio stimulation of collagen in striated skin (Figure 13).

\subsection{Acnes}

The incidence of acne vulgaris was associated with increased oxidative stress, so we understand that treating acne with ozone therapy should be associated with 


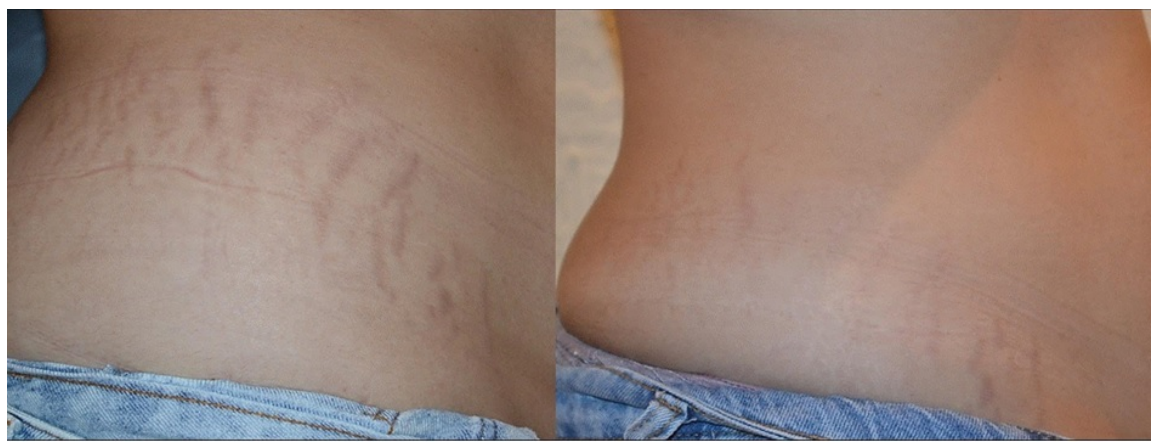

Figure 13. Stretch mark treatment with ozone therapy (Concentration: $10 \mu \mathrm{g}$ : volume: 1 $\mathrm{ml}$ per point; frequency: once every 20 days; total of 5 treatment sessions).

systemic effect techniques for greater action to reduce oxidative stress [45]. Ozone is an agent capable of acting on acne skin in the following way: It reduces inflammatory edema and hyperaemia, softens inflammatory infiltrates, and eliminates acne affection [74].

One study [89] used local injections of ozone (30 and $50 \mu \mathrm{g}$ ) associated with minor autohemotherapy to treat acne in young people aged 14 to 29 years, 3 times a week for one month. After treatment, there was a decrease in inflammatory lesions and edema and regression of pustular eruptions; in addition, there was also a decrease in oxidative stress markers in plasma (Malondialdehyde).

In general, acne can be treated with ozone therapy by washing the area with ozonized water and ozonized soap before injecting ozone; intradermal injection of ozone, using 0.5 to $1.5 \mathrm{ml}$ per injection point, 4 to $15 \mu \mathrm{g}$ of concentration, 1 to 2 times a week [74] [90]. These procedures can be associated with the use of ozonized oil (Peroxide Index. $600 \mathrm{mEq}$ ) for local application 1 to 2 times a day, rectal insufflation (300 - $500 \mathrm{ml} ; 20 \mu \mathrm{g}$ ), minor autohemotherapy (optional), or intravenous infusion of ozonized saline solution (SSO3) (optional) [74] [91].

As for ozonized oil, despite its use being surrounded by some controversy or taboo since acne skin has oily characteristics, it is considered an efficient anti-acne agent. According to some authors [92], ozonized oil has an antiseptic, healing, sebum-regulating, and anti-inflammatory effect in the treatment of acne.

An in vitro study with Cutibacterium acnes used ozonized sunflower and coconut oils to verify their effectiveness in inhibiting the bacteria [93]. Both ozonized sunflower and coconut oils were effective as an antibacterial agent for $\mathrm{Cu}$ tibacterium acnes. A study [92] evaluated the effects of ozonized extra virgin olive oil and ozone-free extra virgin olive oil (control) to treat acne in individuals aged between 10 and 30 years of age. The use of ozonized olive oil for one month revealed that half of the sample of treated individuals had a $75 \%$ cure, and the other half had a $25 \%$ cure. When comparing ozonized olive oil with non-ozonized oil (control), 65\% of the lesions decreased (inflammatory and non-inflammatory) in the group treated with ozonized oil, whereas in the control group, the reduction was only $14.5 \%$.

Ozone therapy has also been shown to be effective in cases of conglobate acne. 
This case is regarding a 34-year-old woman with multiple painful acne lesions for ten years with 10 to 12 red and swollen lesions per day with purulent discharge and a pain level of 10 (scale of 1 to 10). She also had depression and suicidal thoughts resulting from intense chronic pain; drank 12 to 18 beers a day to relieve pain; and was undergoing treatment with antibiotics, steroids, and isotretinoin, but unsuccessfully. The patient showed intense improvement after being treated for one year with ozonized oil (peroxide index $600 \mathrm{mEq}$ ), whole-body bag (10 $\mu \mathrm{g}$ for $20 \mathrm{~min})$, intralesional ozone injections ( $10 \mu \mathrm{g}-4$ to $12 \mathrm{ml}$ injected in the active lesions), and minor auto-hemotherapy ( $5 \mathrm{ml}$ of ozone, $20 \mu \mathrm{g}$, mixed in $5 \mathrm{ml}$ of blood, and injected into the gluteus maximus, $1 \times$ week) [91].

In our clinical practice, the use of ozone has produced excellent results, especially when we use more than one therapeutic modality, such as intralesional injection associated with ozonized oil, as well as associate it with other therapeutic resources, such as LASER or LED, carboxytherapy, microneedling (Figure 14), etc.

\subsection{Scars}

Regarding the stimulation of tissue repair of the skin, ozone therapy, with its most varied therapeutic techniques, has already been shown to be an efficiently proven resource [50]. However, the use of ozone therapy in acute healing processes or Hypertrophic scars or chronic keloids are also common in various places of aesthetic care, although we lack specific studies on the use of ozone in "sequelae" of fibrotic tissues in the field of aesthetics.

However, as previously reported, ozone therapy in the form of ozonized oil could reduce fibrous tissue by stimulating the phagocytic action of excessive collagen fibres in the connective tissue [88], which has guided us to use of ozone in fibrotic scar tissue in the skin. In addition, ozone gas was also able to act specifically on the quality of scar tissue in post-burn formation by producing an antioxidant effect (decreased oxidative stress markers and increased the amount of antioxidant enzymes). It prevented the development of scar fibrosis; together with this, there was an improvement in circulation, providing increased oxygenation, increasing oxygen and ATP in the injured cells, which decreased fibroplasia during healing [94].

Based on this context, our clinical practice recommends the use of ozone in both recent and chronic healing processes because in our understanding, ozone, in addition to accelerating tissue repair, also guarantees quality in healing; however, its main aesthetic application is in cases of hypertrophic scars or Anas keloids. Currently, we have seen an intense aesthetic improvement of the scar tissue when we apply intracatricial ozone (Figure 15).

\subsection{Dyschromia}

Based on the literature, Ozone therapy may be indicated not only for the treatment of hyperchromia but also for hypochromia or achromia. Authors have reported that increased oxidative stress is associated with dyschromia, such as melasma 


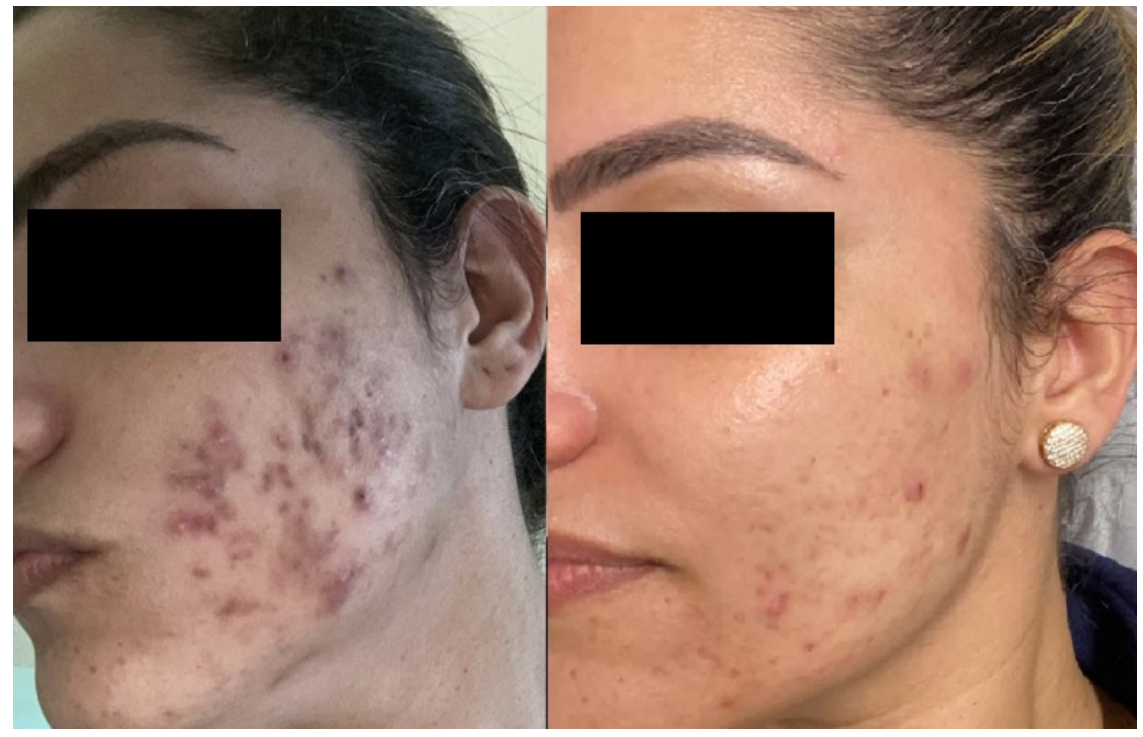

Figure 14. Acne treatment with local ozone injection $(2 \mathrm{ml}$ per point, $10 \mu \mathrm{g}$, once a week, 6 treatment sessions) is associated with microneedling and skin cleansing. (Provided by Carina Queiroz-Belo Horizonte-MG).
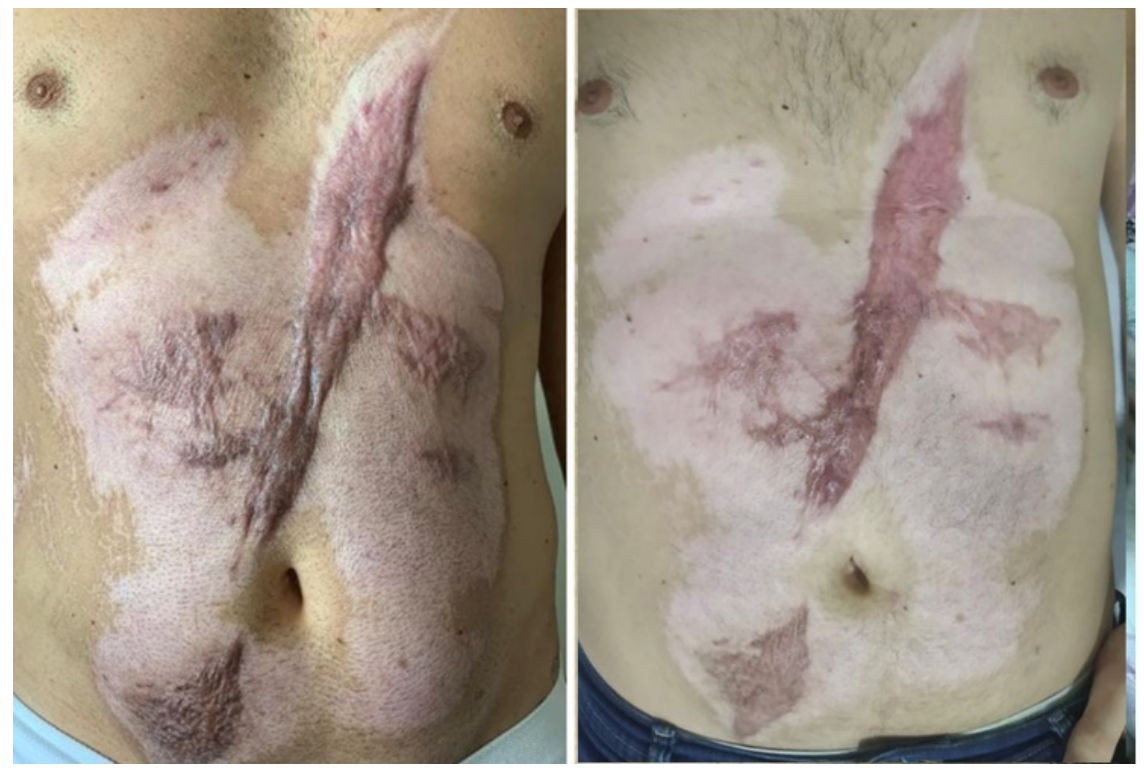

Figure 15. Treatment of a hypertrophic scar in the thoracic-abdominal region after a car accident. It was treated with 4 sessions of intralesional injections (concentration of 5 $\mu \mathrm{g}$; volume $2 \mathrm{ml}$ at each point). Taping was associated for 48 hours. (Provided by Milena Esmeraldo-Fortaleza-CE).

and vitiligo [46] [50] [95] [96] [97]. Therefore, in our clinical practice, we always recommend some systemic ozone therapy to reduce oxidative stress (especially rectal insufflation) and, thus, assist in the treatment of the dyschromia mentioned above.

In post-skin injury hyperchromia (restorative or inflammatory) cases, we have recommended treatment with the injection of ozone into the skin or the topical use of ozonized oil. The recommendation by some authors [98] who reported 
that hydrogen peroxide $\left(\mathrm{H}_{2} \mathrm{O}_{2}\right)$ acts in the early stages of melanogenesis and the oxidizing environment within the melanosome, regulating melanin synthesis (acts under tyrosinase). The authors even admitted the possibility of using creams with depigmenting action containing hydrogen peroxide to treat this type of hyperchromia.

Still, on ozonized oil and its action on hyperchromia, authors compared the effects of ozonized oil with topical hyaluronic acid (gel, 0.2\%) in treating skin burns (used once a day, for 12 weeks). The authors reported that ozonized oil was as effective as hyaluronic acid in reducing burn-related symptoms to the skin, but it appeared to be more effective in reducing post-injury hyperpigmentation [99].

Regarding age spots associated with skin aging, a case report was found [84] with intense reduction of facial spots and reduction and/or elimination of wrinkles and improvement in dermal turgor (face and neck) after skin bio stimulation with weekly ozone injections.

In severe cases of achromia, such as vitiligo, systemic ozone therapy seems to be the best treatment method, as 50 patients had the levels of antioxidant markers evaluated (superoxide dismutase, glutathione peroxidase, glutathione, malonic dialdehyde, 8-OH-deoxyguanosine), and were treated with intravenous injection of ozonized saline solution ( $300-400 \mathrm{ml}$, for 30 to 60 minutes), 3 times a week, totalling 9 to 10 procedures. As a result, the progression of vitiligo was stopped in 40 patients $(80 \%)$ with diffuse or punctual repigmentation and a decrease around depigmented spots. In addition, there was also a normalization of oxidative stress indices with a decrease in malonic dialdehyde and 8-OH-deoxyguanosine. There is also an increase in the concentration of glutathione and glutathione peroxidase on average by 1.5 times [46].

Based on the above, and based on our clinical experience, we understand that local injections, especially in case of hyperchromia, the use of ozonized oil or cosmetics, almost always associated with systemic ozone therapy (rectal insufflation, intravenous injection of ozonized saline solution and auto-hemotherapy) can be excellent therapeutic options in several cases of dyschromia, especially those verified after aesthetic treatments (plasma jet, fractional radiofrequency, microneedling, peelings, etc.).

\section{Final Considerations}

In addition to the aesthetic affections described in this study, we still found support for the use of ozone therapy in other clinical situations, such as telangiectasias, hair therapy. We are also using it in an "experimental" along with electrolypolysis in replacement of carboxytherapy in the technique of Electrocarbolypolysis, as well as in aesthetic skin cleaning using ozonized water compresses, in hydrolipoclasis with ozonized saline solution injected directly into the subcutaneous fat, associating the use of sound waves (ultrasound, ultracavitation or shock waves), and after microneedling (ozonized oil) [13] [74] [100] [101]. 
Based on the above in our clinical practice, we conclude that ozone therapy through its various therapeutic modalities (systemic or local applications: transcutaneous, intradermal, and subcutaneous) has added a lot to aesthetic procedures, mainly due to its effective adjuvant action or as the main agent of critical physiological changes to enhance clinical results, in addition, we find many reports in the world literature for the use of ozone in the treatment of aesthetic dysfunctions, thus ensuring the necessary support for its use in this area of professional activity, as for several decades, such as Russia [8] [10], Spain [74], Turkey [16], Italy [14] [15], Brazil [84] have already published their studies in several publications showing effective results of the use of ozone therapy in treatment of esthetic dysfunctions, therefore, we believe that currently there is great support and consistent justification for all professionals who treat esthetic affections using the various therapeutic modalities available in ozone therapy.

\section{Conflicts of Interest}

The authors declare no conflicts of interest regarding the publication of this paper.

\section{References}

[1] Rubin, M.B. (2001) The History of Ozone-The Schönbein Period, 1839-1868. Bulletin for the History of Chemistry, 26, 40-56.

[2] Rideal, E.K. (1920) The Manufacture of Chemicals by Electrolysis. Ozone. Constable, London. https://archive.org/details/ozonerid00rideuoft

[3] Nogales, C.G., Ferrari, P.H., Kantorovich, E.O. and Lage-Marques, J.L. (2008) Ozone Therapy in Medicine and Dentistry. The Journal of Contemporary Dental Practice, 9, 75-84. https://doi.org/10.5005/jcdp-9-4-75

[4] Elvis, A.M. and Ekta, J.S. (2011) Ozone Therapy: A Review. Journal of Natural Science Biology and Medicine, 2, 66-71. https://doi.org/10.4103/0976-9668.82319

[5] Wentworth, P. (2003) Evidence for Antibody-Catalyzed Ozone Formation in Bacterial Killing and Inflammation. Science, 298, 2195-2199. https://doi.org/10.1126/science.1077642

[6] Babior, B., Takeuchi, C., Ruedi, J., Gutierrez, A. and Wentworth Jr., P. (2003) Investigating Antibody-Catalyzed Ozone Generation by Human Neutrophils. Proceedings of the National Academy of Sciences of the United States of America, 100, 30313034. https://doi.org/10.1073/pnas.0530251100

[7] Kosheleva, I.V. and Vyaznikova, N.I. (2004) Minimally Invasive Correction of Some Cosmetic Imperfections Using Medical Ozone. Experimental and Clinical Dermatocosmetology, 6C, 18-21.

[8] Kosheleva, I.V. (2004) Ozone Therapy in Dermatology and Cosmetology: Achievements of the Problem, Prospects. Russian Journal of Skin and Venereal Diseases, 1 , 28-32.

[9] Tkachenko, S.B., et al. (2004) Evaluation of the Influence of Oxygen-Ozone Therapy on the Skin Condition in Cellulite Using Ultrasonic Dermoscanning. Experimental and Clinical Dermatocosmetology, 2, 39-42.

[10] Kosheleva, I.V. (2000) The Use of a Mixture of Oxygen and Ozone in Dermatology and Medical Cosmetology. Cosmetics and Medicine, 4, 69-75. 
[11] Cardoso, O., Rossi, P., Galoforo, A. and Collodo, G. (2018) Ozone Therapy in Painful Lipodystrophies. A Preliminary Study. Ozone Therapy, 3, Article 7510. https://doi.org/10.4081/ozone.2018.7510

[12] Sirito, M.A. (2006) Oxygen-Ozone Therapy for Local Adipose Deposits and Edematous Fibroesclerotic Panniculopathy. Rivista Italiana di Ossigeno Ozonoterapia, 5, 37-39.

[13] Bocci, V. (2010) The Clinical Application of Ozone Therapy. In: OZONE, Springer, Dordrecht, 97-232. https://doi.org/10.1007/978-90-481-9234-2 9

[14] Cuccio, G. and Franzini, M. (2016) Oxygen-Ozone Therapy in the Treatment of Tissue Adipose Diseases. Ozone Therapy, 1, 25-33. https://doi.org/10.4081/ozone.2016.6270

[15] Galoforo, A.C., et al. (2002) Valutazione della validità dell'Ossigeno Ozonoterapia nel trattamento della PEFS. Rivista Italiana di Ossigeno-Ozonoterapia, 1, 87-92.

[16] Bas, S. and Yula, E. (2018) Overview of Dermatological Ozone Applications and a Rare Complication of Dermal Ozone Treatment: Isolated Orbital Emphysema with Cutaneous Injection. Journal of Immunology and Clinical Microbiology, 3, 38-49.

[17] Viebahn-Hänsler, R., Fernández, O.S.L. and Fahmy, Z. (2012) Ozone in Medicine: The Low-Dose Ozone Concept-Guidelines and Treatment Strategies. Ozone. Science \& Engineering, 34, 408-424. https://doi.org/10.1080/01919512.2012.717847

[18] Viebahn-Hänsler, R. and Lee, A. (2002) The Use of Ozone in Medicine: A Practical Handbook. 4th Revised Edition, Medicina Biologica, Iffezheim.

[19] Zeng, J. and Lu, J. (2018) Mechanisms of Action Involved in Ozone-Therapy IN Skin Diseases. International Immunopharmacology, 56, 235-241.

https://doi.org/10.1016/j.intimp.2018.01.040

[20] Barreto, R.L., Correia, C.R.D. and Muscaráos, M.N. (2005) Óxido nítrico: Propriedades e utilizações terapêuticas. Química Nova, 28, 1046-1054. https://doi.org/10.1590/S0100-40422005000600020

[21] Cedeño, B.E., Rodríguez, A.A. and Hernández, R.R. (2020) Ozonoterapia rectal en pacientes con osteoartritis. Revista Cubana de Medicina, 59, e1323.

[22] Bocci, V., Zanardi, I. and Travagli, V. (2011) Ozone Acting on Human Blood Yields a Hormetic Dose-Response Relationship. Journal of Translational Medicine, 9, Article No. 66. https://doi.org/10.1186/1479-5876-9-66

[23] Simonetti, V., Liboni, W. and Molinari, F. (2014) Why Ozone Therapy in Multiple Sclerosis? Revista Española de Ozonoterapia, 4, 51-68.

[24] Zeng, J., et al. (2020) Ozone Therapy Attenuates NF- $\kappa$ B-Mediated Local Inflammatory Response and Activation of Th17 Cells in Treatment for Psoriasis. International Journal of Biological Sciences, 16, 1833-1845. https://doi.org/10.7150/ijbs.41940

[25] Valdés, R., et al. (2015) Ozonoterapia como alternativa de tratamiento del dolor en los trastornos temporomandibulares. Revista Europea de Odonto-Estomatología, 13, 2-8.

[26] Ramírez, M.R.B. (2014) Evaluacion del efecto de la ozonoterapia en perros con problemas de dermatitis bacteriana en la ciudad de cuenca provincia del Azuay. Tesis previa a la obtención del titulo de Medico Veterinario Zootecnicista, Univ Politécnica Salesiana, Cuenca, Ecuador.

[27] Glezer, I., Marcourakis, T., Avellar, M.C.W., Gorenstein, C. and Scavone, C. (2000) O fator de transcrição NF-kB nos mecanismos moleculares de ação de psicofármacos. Revista Brasileira de Psiquiatria, 22, 26-30. https://doi.org/10.1590/S1516-44462000000100008

[28] Schwartz, A. (2016) Ozonized Saline Solution (O3SS): Scientific Foundations. Re- 
vista Española de Ozonoterapia, 6121-129.

[29] Schneider, K.S. and Chan, J.Y. (2013) Emerging Role of Nrf2 in Adipocytes and Adipose Biology. Advances in Nutrition, 4, 62-66.

https://doi.org/10.3945/an.112.003103

[30] Hahn, G.F., de Oliveira, J.R. and Bock, P.M. (2017) O papel do fator nuclear eritroide 2 relacionado ao fator 2 (Nrf2) no diabetes mellitus. Clinical and Biomedical Research, 37, 203-213. https://doi.org/10.4322/2357-9730.73884

[31] Menendez-Cepero, S. (2020) Therapeutic Effects of Ozone Therapy That Justifies Its Use for the Treatment of COVID-19. Journal of Neurology and Neurocritical Care, 3, 2-6. https://doi.org/10.31038/JNNC.2020314

[32] Ahmed, S.M.U., Luo, L., Namani, A., Wang, X.J. and Tang, X. (2017) Nrf2 Signaling Pathway: Pivotal Roles in Inflammation. Biochimica et Biophysica Acta, 1863, 585597. https://doi.org/10.1016/j.bbadis.2016.11.005

[33] Galiè, M., Covi, V., Tabaracci, G. and Malatesta, M. (2019) The Role of Nrf2 in the Antioxidant Cellular Response to Medical Ozone Exposure. International Journal of Molecular Sciences, 20, 4009. https://doi.org/10.3390/ijms20164009

[34] Re, L., et al. (2014) Is Ozone Pre-Conditioning Effect Linked to Nrf2/EpRE Activation Pathway in Vivo? A Preliminary Result. European Journal of Pharmacology, 742, 158-162. https://doi.org/10.1016/j.ejphar.2014.08.029

[35] Delgado-Roche, L., et al. (2017) Medical Ozone Promotes Nrf2 Phosphorylation Reducing Oxidative Stress and Pro-Inflammatory Cytokines in Multiple Sclerosis Patients. European Journal of Pharmacology, 811, 148-154. https://doi.org/10.1016/j.ejphar.2017.06.017

[36] Smith, N.L., Wilson, A.L., Gandhi, J., Vatsia, S. and Khan, S.A. (2017) Ozone Therapy: An Overview of Pharmacodynamics, Current Research, and Clinical Utility. Medical Gas Research, 7, 212-219. https://doi.org/10.4103/2045-9912.215752

[37] Véliz Gutiérrez, J.A., Diaz, N.P., Montequín, Z.F., Negrín, J.S. and Arias, A.M. (2009) Aceite ozonizado: Alternativa efectiva para las ulceras varicosas de miembros inferiores en atención primaria. Revista de Ciencias Médicas de Pinar del Río, 13, 18-24.

[38] Marchesini, B.F. and Ribeiro, S.B. (2020) Efeito da ozonioterapia na cicatrização de feridas. Fisioterapia Brasil, 21281-288. https://doi.org/10.33233/fb.v21i3.2931

[39] Bocci, V. (1994) Autohemotherapy after Treatment of Blood with Ozone. A Reappraisal. Journal of International Medical Research, 22, 131-144.

https://doi.org/10.1177/030006059402200301

[40] Nagayoshi, M., Fukuizumi, T., Kitamura, C., Yano, J., Terashita, M. and Nishihara, T. (2004) Efficacy of Ozone on Survival and Permeability of Oral Microorganisms. Oral Microbiology and Immunology, 19, 240-246. https://doi.org/10.1111/j.1399-302X.2004.00146.X

[41] Jung, K.A. and Kwak, M.-K. (2010) The Nrf2 System as a Potential Target for the Development of Indirect Antioxidants. Molecules, 15, 7266-7291. https://doi.org/10.3390/molecules 15107266

[42] Farage, N.E. (2016) Expressão dos fatores de transcrição Nrf2 e NF- $\kappa$ B e associação com estado nutricional em pacientes renais crônicos em hemodiálise. Tese submetida ao Programa de Pós-Graduação em Ciências Médicas da Universidade Federal Fluminense como parte dos requisitos necessários à obtenção do Grau de Doutora. Área de Concentração: Ciências Médicas. https://app.uff.br/riuff/bitstream/1/4615/1/Tese\%20NAJLA\%20ELIAS.pdf

[43] Sagai, M. and Bocci, V. (2011) Mechanisms of Action Involved in Ozone Therapy: 
Is Healing Induced via a Mild Oxidative Stress? Medical Gas Research, 1, Article No. 29. https://doi.org/10.1186/2045-9912-1-29

[44] Sarkar, R., Devadasan, S., Choubey, V. and Goswami, B. (2020) Melatonin and Oxidative Stress in Melasma-An Unexplored Territory; a Prospective Study. International Journal of Dermatology, 59, 572-575. https://doi.org/10.1111/ijd.14827

[45] Mills, O.H., et al. (2016) Lidando com a Oxidação de Radicais Livres na Acne Vulgaris. The Journal of Clinical and Esthetic Dermatology, 9, 25-30.

[46] Gereykhanova, L.G., Lomonosov, K.M. and Melnikova, Y.G. (2017) Results of Oxygen-Ozone Mix in the Treatment of Vitiligo. Russian Journal of Skin and Venereal Diseases (Rossiyskii Zhurnal Kozhnykh i Venericheskikh Boleznei), 20, 290-292. (In Russian) https://doi.org/10.18821/1560-9588-2017-20-5-290-292

[47] Poliychuk, T.P. (2010) Oxygen-Ozone Therapy for Patients with Localized Fat Deposits. Thesis of the Higher Certification Commission of the Russian Federation, Candidate for Medical Sciences: 14.01.10, Skin and Venereal Diseases. St. Petersburg Medical Academy of Postgraduate Education of the Federal Agency for Healthcare and Social Development. 151s.

https://www.dissercat.com/content/kislorodno-ozonovaya-terapiya-patsientov-s-lo kalnymi-zhirovymi-otlozheniyami/read

[48] Siems, W., Grune, T., Voss, P. and Brenke, R. (2005) Anti-Fibrosclerotic Effects of Shock Wave Therapy in Lipedema and Cellulite. Biofactors, 24, 275-282.

https://doi.org/10.1002/biof.5520240132

[49] Conti, G., et al. (2020) Proteomic and Ultrastructural Analysis of Cellulite-New Findings on an Old Topic. International Journal of Molecular Sciences, 21, 2077. https://doi.org/10.3390/ijms21062077

[50] Clinical Effectiveness of Medical Ozone Therapy (2020) VHL Evidence Map [Online]. BIREME/PAHO/WHO, São Paulo. Clinical Effectiveness of Ozone Therapy, BVS MTCI. https://bvsalud.org/

[51] Ohmine, S. (2005) Investigation of the Mechanisms of Ozone-Mediated Viral Inactivation. MS Thesis, Brigham Young University, Provo, UT, 597.

https://scholarsarchive.byu.edu/etd/597

[52] Dunnill, C., et al. (2017) Reactive Oxygen Species (ROS) and Wound Healing: The Functional Role of ROS and Emerging ROS-Modulating Technologies for Augmentation of the Healing Process. International Wound Journal, 14, 89-96. https://doi.org/10.1111/iwj.12557

[53] Rodrigues, K.L., et al. (2004) Cicatrizing and Antimicrobial Properties of an Ozonised Oil from Sunflower Seeds. InflammoPharmacology, 12, 261-270. https://doi.org/10.1163/1568560042342275

[54] Baldizón, M.R.L. (2017) Uso combinado de ozonoterapia y fibrina autóloga rica en Plaquetas y leucocitos (L-PRF) en el tratamiento de úlceras cutáneas. Revista Es pañola de Ozonoterapia, 7, 59-65.

[55] Kim, H.S., et al. (2009) Therapeutic Effects of Topical Application of Ozone on Acute Cutaneous Wound Healing. Journal of Korean Medical Science, 24, 368-374.

[56] Heilin, J., et al. (2011) Plasma Applications in Medicine with a Special Focus on Dermatology. Journal of the European Academy of Dermatology and Venereology, 25, 1-11. https://doi.org/10.1111/j.1468-3083.2010.03702.x

[57] Pereira, B.A., et al. (2016) Ozonioterapia no tratamento de ferida em cão-Relato de casos. XVI Fórum de Pesquisa, Universidade Luterana do Brasil, Canoas.

[58] Soares, C.D., et al. (2019) Effects of Subcutaneous Injection of Ozone during Wound 
Healing in Rats. Growth Factors, 37, 95-103. https://doi.org/10.1080/08977194.2019.1643339

[59] Sen, C.K., Khanna, S., Babior, B.M., Hunt, T.K., Ellison, E.C. and Roy, S. (2002) Oxidant-Induced Vascular Endothelial Growth Factor Expression in Human Keratinocytes and Cutaneous Wound Healing. Journal of Biological Chemistry, 277, 33284-33290. https://doi.org/10.1074/jbc.M203391200

[60] Borges, G.A., et al. (2017) In Vitro Evaluation of Wound Healing and Antimicrobial Potential of Ozone Therapy. Journal of Cranio-Maxillofacial Surgery, 45, 364-370. https://doi.org/10.1016/j.jcms.2017.01.005

[61] Valacchi, G., et al. (2010) Evaluation of Ozonated Sesame Oil Effect in Wound Healing Using the SKH1 Mice as a Model. Proceeding of the 7 th World Meeting on Pharmaceutics, Biopharmaceutics and Pharmaceutical Technology, Valletta, Malta, March 2010, 8-11.

[62] Travagli, V., Zanardi, I., Valacchi, G. and Bocci, V. (2010) Ozone and Ozonated Oils in Skin Diseases: A Review. Mediators of Inflammation, 2010, Article ID: 610418. https://doi.org/10.1155/2010/610418

[63] Hidayat, A.T., Arifin, M.T., Nur, M., Muniroh, M. and Susilaningsih, N. (2021) Ozonated Aloe vera Oil Effective Increased the Number of Fibroblasts and Collagen Thickening in the Healing Response of Full-Thickness Skin Defects. International Journal of Inflammation, 2021, Article ID: 6654343. https://doi.org/10.1155/2021/6654343

[64] Tamba, U.S., Arifin, M.T., Nur, M., Muniroh, M. and Susilanigsih, N. (2020) The Role of Ozonated Aloe vera Oil in Full-Thickness Skin Defects: Macrophage Count and Epithelization Length Parameter. F1000Research, 9, 1218.

https://doi.org/10.12688/f1000research.25063.1

[65] Bocci, V. (2011) Ozone: A New Medical Drug. 2nd Edition, Springer, Netherlands. https://doi.org/10.1007/978-90-481-9234-2

[66] Lim, Y., et al. (2006) Modulation of Cutaneous Wound Healing by Ozone: Differences between Young and Aged Mice. Toxicology Letters, 160, 127-134.

https://doi.org/10.1016/j.toxlet.2005.06.013

[67] Vasconcelos, S.M.L., et al. (2007) Espécies reativas de oxigênio e de nitrogênio, antioxidantes e marcadores de dano oxidativo em sangue humano: Principais métodos analíticos para sua determinação. Química Nova, 30, 1323-1338.

https://doi.org/10.1590/S0100-40422007000500046

[68] Cisterna, B., et al. (2020) Ozone Activates the Nrf2 Pathway and Improves Preservation of Explanted Adipose Tissue in Vitro. Antioxidants, 9, 989. https://doi.org/10.3390/antiox9100989

[69] Moreno-Navarrete, J.M., et al. (2013) The MRC1/CD68 Ratio Is Positively Associated with Adipose Tissue Lipogenesis and with Muscle Mitochondrial Gene Expression in Humans. PLoS ONE, 8, e70810. https://doi.org/10.1371/journal.pone.0070810

[70] Kara, Ö. and Kara, M. (2019) Lipolysis of a Painful Lipoma with Ozone: The Role of Ultrasound in the Diagnosis and Quantification of the Treatment. Medical Gas Research, 9, 168. https://doi.org/10.4103/2045-9912.267000

[71] Thakkar, V. and Thakkar, H. (2014) Ozone (O3): An Excellent Adjunctive Tool in Medical and Surgical Management of Patient. International Journal of Research in Medical Sciences, 2, 1257-1261. https://doi.org/10.5455/2320-6012.ijrms20141104

[72] Borelli, E., De monte, A. and Bocci, V. (2015) Oxygen Ozone Therapy in the Integrated Treatment of Chronic Ulcer: A Case Series Report. International Journal of 
Recent Scientific Research, 6, 4132-4136.

[73] Ashem, H.N. and Nagib, S.H. (2011) Ozone Therapy as an Adjunctive Modality for Weight Reduction in Grade II Adult Obese Subjects. Bulletin of Faculty of Pharmacy, Cairo University, 16, 71-77.

[74] Schwartz, A. (2017) Manual de Ozonoterapia Clínica. Soluciones Médicas, Madrid.

[75] Shallenberger, F. (2017) The Ozone Miracle: How You Can Harness the Power of Oxygen to Keep You and Your Family Healthy. CreateSpace Independent Publishing Platform, Scotts Valley, CA.

[76] Horan, P. (2016) Heal Yourself with Ozone: Practical Suggestions for Oxygen Based Approaches to Healing. CreateSpace Independent Publishing Platform, Scotts Valley, CA.

[77] ISCO3 (2020) Madrid Declaration on Ozone Therapy. 3rd Edition, The International Scientific Committee of Ozone Therapy, Madrid, 20. http://www.isco3.org/

[78] Adler, A.S., et al. (2007) Motif Module Map Reveals Enforcement of Aging by Continual NF-kappaB Activity. Genes \& Development, 21, 3244-3257. https://doi.org/10.1101/gad.1588507

[79] Yu, G., et al. (2016) Ozone Therapy Could Attenuate Tubulointerstitial Injury in Adenine-Induced CKD Rats by Mediating Nrf2 and NF-B. Iranian Journal of Basic Medical Sciences, 19, 1136-1143.

[80] Manfredi, G. and Apuzzo, D. (2020) Successful Ozone Treatment of EBV and HSV-Related Viral Urticaria. Frontiers in Medical Case Reports, 1, 1-6. https://doi.org/10.47746/FMCR.2020.1202

[81] Ganceviciene, R., Liakou, A.I., Theodoridis, A., Makrantonaki, E. and Zouboulis, C.C. (2012) Skin Anti-Aging Strategies. Dermato-Endocrinology, 4, 308-319. https://doi.org/10.4161/derm.22804

[82] Ivanova, E.V. (2007) Pathogenetic Justification of Application of Oxygen-Ozone Mixture in Correction of Age Changes in the skin. Candidate in Medical Sciences. 140011 -Skin and Venereal Diseases. Higher Education Institution of Higher Professional Education of the Moscow Medical Academy, Moscow.

https://www.dissercat.com/content/patogeneticheskoe-obosnovanie-primeneniya-ki slorodno-ozonovoi-smesi-v-korrektsii-vozrastnykh/read

[83] Makita, Y., et al. (2015) The Effect of Ozone on Collagen Type-1 and Inflammatory Cytokine Production in Human Gingival Fibroblasts. Dentistry, 5, Article ID: 1000339.

[84] Lacerda, A.C., Grillo, R., Pessoa de Barros, T.E., Martins, C.B. and de Carvalho Luposeli, F. (2021) Efficacy of Biostimulatory Ozone Therapy: Case Report and Literature Review. Journal of Cosmetic Dermatology.

[85] Sahin, H., et al. (2016) The Acute Effects of Preoperative Ozone Therapy on Surgical Wound Healing. Acta Cirúrgica Brasileira, 31, 472-478. https://doi.org/10.1590/S0102-865020160070000007

[86] Repciuc, C., Toma, C.G., Ober, C.A. and Oana, L.I. (2020) Management of surgical Wound Dehiscence by Oxygen-Ozone Therapy in a FIV-Positive Cat-A Case Report. Acta Veterinaria Brno, 89, 189-194. https://doi.org/10.2754/avb202089020189

[87] Uysal, B., et al. (2012) Medical Ozone Therapy Decreases Postoperative Uterine Adhesion Formation in Rats. Archives of Gynecology and Obstetrics, 286, 1201-1207. https://doi.org/10.1007/s00404-012-2435-y

[88] Patel, P.V. and Gujjari, S.K. (2013).The Morphometrical and Histopathological Changes Which Were Observed after Topical Ozone Therapy on an Exophytic Fibr- 
ous Gingival Lesion: A Case Report. Journal of Clinical and Diagnostic Research, 7, 1239-1243. https://doi.org/10.7860/JCDR/2013/4963.3039

[89] Nikulin, N., Bitkina, O.A., Philippova, L.I. and Kopytova, T.V. (2005) Dynamics of Lipid Peroxidation Indices under Influence of Ozone Therapy in Patients with Complicated Forms of Rosacea and Acne Disease. IOA 17 th World Ozone Congress, Strasbourg, 1-5.

https://lomr.org/dynamics-of-lipid-peroxidation-indices-under-influence-of-ozonetherapy-in-patients-with-complicated-forms-of-rosacea-and-acne-disease/

[90] Polizo, A. and Nedelciuc, A. (2020) Ozone Therapy in the Treatment of an Acne Vulgaris. MedEspera: The 8th International Medical Congress for Students and Young Doctors, Chișinău, 24-26 September 2020, 29-30.

https://medespera.asr.md/wp-content/uploads/ABSTRACT-BOOK.pdf

[91] G. Davis, V. (2018) Clinical Improvement of Severe Chronic Acne Conglobata. Case Report. Revista Española de Ozonoterapia, 8, 109-115.

[92] Khaoshi, X. and Zhang, C. (2020) Formulation and Clinical Evaluation of Ozonated Olive Oil for the Treatment of Acne Vulgaris Lesions. Stem Cell, 11, 54-60. http://www.sciencepub.net/stem

[93] Rensi, A., et al. (2014) Avaliação do efeito de óleos ozonizados de girassol e coco no controlo da Propionibacterium acnes. XXIV Congresso de Engenharia Biomédica, $C B E B, 1164-1166$.

https://www.canal6.com.br/cbeb/2014/artigos/cbeb2014 submission 347.pdf

[94] Guven, A. (2008) The Efficacy of Ozone Therapy in Experimental Caustic Esophageal Burn. Journal of Pediatric Surgery, 43, 1679-1684.

https://doi.org/10.1016/j.jpedsurg.2008.01.064

[95] Seçkin, H.Y., et al. (2014) Oxidative Stress Status in Patients with Melasma. Cutaneous and Ocular Toxicology, 33, 212-217. https://doi.org/10.3109/15569527.2013.834496

[96] Choubey, V., et al. (2017) Role of Oxidative Stress in Melasma: A Prospective Study on Serum and Blood Markers of Oxidative Stress in Melasma Patients. International Journal of Dermatology, 56, 939-943. https://doi.org/10.1111/ijd.13695

[97] Gereykhanova, L.G., Lomonosov, K.M. and Bashlakova, K.A. (2016) Oxidative Stress in the Pathogenesis of Vitiligo and Methods of Its Correction. Russian Jour nal of Skin and Venereal Diseases, 19, 45-48.

https://cyberleninka.ru/article/n/okislitelnyy-stress-v-patogeneze-vitiligo-i-metodyego-korrektsii https://doi.org/10.18821/1560-9588-2016-19-1-45-48

[98] García-Molina, F., et al. (2005) Opposite Effects of Peroxidase in the Initial Stages of Tyrosinase-Catalysed Melanin Biosynthesis. The International Journal of Biochemistry \& Cell Biology, 37, 1179-1196. https://doi.org/10.1016/j.biocel.2004.11.009

[99] Campanati, A., et al. (2013) Topical Ozonated Oil versus Hyaluronic Gel for the Treatment of Partial- to Full-Thickness Second-Degree Burns: A Prospective, Comparative, Single-Blind, Non-Randomised, Controlled Clinical Trial. Burns, 39, 1178 1183. https://doi.org/10.1016/j.burns.2013.03.002

[100] Voronkova, M.V., et al. (2012) [Treatment of Cicatricial Alopecia] Лечение рубцовых алопеций. Российский журнал кожных и венерических болезней, УДК 616.594.1002.158-08. (In Russian)

[101] Schneiberg, R.T. and Franciscon, G.B. (2016) Gordura Localizada: Abordagem Terapêutica. In: Borges, F.S. and Scorza, F.A., Eds., Terapêutica em Estética-Conceitos e Técnicas, Phorte, São Paulo, 373 p. 